\title{
Prevalence of Anticoagulant Rodenticide Exposure in Red-tailed Hawks (Buteo jamaicensis) in New York State and Diagnostic Utility of Russell Viper Venom Test for Detecting Associated Coagulopathies
}

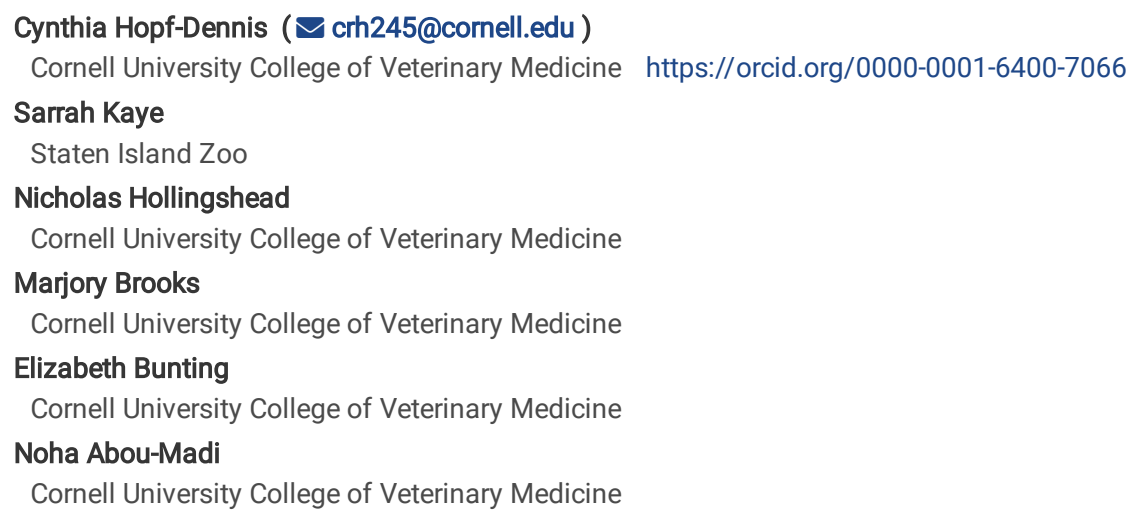




\section{Abstract}

Anticoagulant rodenticides (ARs) continue to be used across the United States as a method for controlling unwanted rodent species. As a consequence, wild birds of prey are exposed to toxins by eating poisoned prey items. ARs prevent the hepatic recycling of vitamin $\mathrm{K}$ and thereby impede the post-translational processing of coagulation factors II, VII, IX, and X that is required for procoagulant complex assembly. Through this mechanism of action, ARs cause hemorrhage and death in their target species. Various studies have documented the persistence of these contaminants in birds of prey but few have attempted to use affordable and accessible diagnostic tests to diagnose exposure in free-ranging birds of prey. In our study free-ranging red-tailed hawks were found to be exposed to difethialone and brodifacoum. Eleven of sixteen (68\%) livers tested for AR exposure were positive. Difethialone was found in 1/16 (6\%) liver samples, and brodifacoum was detected in 15/16 (93\%) liver samples. Difethialone was found at a concentration of $0.18 \mathrm{ppm}$ and brodifacoum concentrations ranged from $0.003-0.234 \mathrm{ppm}$. Two out of $34(6 \%)$ RTH assessed for blood rodenticide had brodifacoum in blood with measured concentrations of 0.003 and $0.006 \mathrm{ppm}$. The range of clotting times in the prothrombin time (PT) and Russell's viper venom time assays for control RTH were 16.7 to 39.7 seconds and 11.5 to 91.8 seconds, respectively. No correlation was found between PT and RVVT in the control or free-range RTH, and there was no relationship found between the presence of liver anticoagulant residues and clotting times in the PT and RVVT.

\section{Introduction}

Anticoagulant rodenticide (AR) exposure in wildlife is a global problem impacting a variety of wildlife species (Slankard 2019, Hydock 2017, Elliott 2014, Stansley 2014, Thomas 2011, Stone 2003, Hindmarch 2019, Elmeros 2019, Lambert 2007, Albert 2010, Newton 2002, Lohr 2018, Seljetun 2020, Murray 2020, Lopez-Perea 2018, Ruiz-Suarez 2014). Anticoagulant rodenticides exert their action by preventing the hepatic recycling of vitamin $\mathrm{K}$ and thereby impeding the post-translational processing of coagulation factors II, VII, IX, and X that is required for procoagulant complex assembly. Following development of resistance to first-generation toxins, such as warfarin, second-generation AR were developed (Jackson and Kaukeinen 1972, Buckle et al. 1994). Second-generation ARs have been shown to have longer elimination half-lives in serum and liver of mice, are more potent, and only need to be consumed once to produce death (Vandenbroucke et al. 2008, Buckle and Prescott 2018)._As an example, brodifacoum showed a plasma elimination half-life of 91.7 days and liver half-life of 307.4 days in laboratory mice (Vandenbroucke et al. 2008). Second generation rodenticides include brodifacoum, bromadiolone, difenacoum, diphacinone, and chlorophacinone. Currently brodifacoum and bromadiolone are two products that are available for use by licensed pesticide applicators only (US EPA).

Anticoagulant rodenticide applications are highly regulated by the United States Environmental Protection Agency (US EPA) but are still frequently used for pest control (Jacob and Buckle 2018, Witmer 2018, Buckle and Prescott 2018, Anderson et al. 2011, Memmott et al. 2017). Despite restrictions placed by the EPA in 2008 to mitigate secondary exposure to wild mammals and birds, AR toxicities and exposure continue to be reported in both domestic and nondomestic non-target species (Anderson et al. 2011, DuVall et al. 1989, Kohn et al. 2003, Borst and Counotte 2002, Elliott et al. 2014, Elmeros et al. 2019, Hindmarch et al. 2019, López-Perea and Mateo 2018, Hydock et al. 2017, Kelly et al. 2014, Slankard et al. 2019). High-level exposure via ingestion of these products results in uncontrolled bleeding, hypovolemic shock, and death (Rattner, Lazarus et al. 2014, DuVall et al. 1989, Murphy and Gerkin 1989). In secondarily exposed birds, the effects of repeated, sub-lethal exposure and survival rates are poorly characterized. Raptors, including red-tailed hawks (RTH) (Buteo jamaicensis) are highly susceptible to non-target AR exposure presumptively from consuming intoxicated prey (Murray 2011, Stansley et al. 2014, Stone et al. 1999, Stone et al. 2003, Thomas et al. 2011).

It can be difficult to determine the morbidity resulting from non-target rodenticide exposure, particularly in wild birds. Methods of estimating AR exposure in free-ranging raptors consist of measuring blood AR levels in injured or sick raptors that present to wildlife hospitals, and/or analyzing livers for AR residues during post-mortem examinations. Multiple ecological studies had established high anticoagulant exposure burden in free-ranging raptors through Massachusetts, New York, and New Jersey (Stone 2003, Stansley 2014, Murray 2011, 2020). Because of the significant risk of exposure, and to better assess the effects of AR exposure on health and survival in birds of prey, veterinarians working with wildlife need ante-mortem tests that allow for rapid and sensitive assessment of coagulopathies resulting from AR and to help establish how AR exposure is related to morbidity in free-ranging raptors. The Russell's viper venom time test (RVVT) is a coagulation screening test configured with a commercially available reagent (Russell's viper venom) that directly activates factor $\mathrm{X}$ zymogen to its active, enzymatic form, factor Xa. Deficiencies of factor X, or the other common pathway factors (factors $\mathrm{V}$, II, fibrinogen) are detected as prolongation of clotting time in the RVVT. Previous research has investigated the use of the RVVT and avian-optimized prothrombin time (PT) assays to detect vitamin K-dependent coagulopathies in raptors experimentally dosed with diphacinone. Results of the RVVT and PT were directly correlated and both tests appeared to be sensitive indicators of anticoagulant rodenticide exposure (Rattner et al. 2011, 2012). Hindmarch et al report a $23 \%$ rate of elevated RVVT or PT in free ranging raptors presented to Orphaned Wildlife Rehabilitation Society (OWL). Hindmarch et al represents the only report of RVVT in free-ranging RTHs until our current report (Hindmarch et al. 2019).

The objectives of this study were (1) to determine anticoagulant rodenticides exposure in a population of red-tailed hawks presenting to a wildlife clinic in Upstate NY through detection of blood and liver AR residues, (2) to determine if coagulation times in clinically exposed birds differs from healthy control birds using three coagulation assays: the PT (using an avian thromboplastin reagent), fibrinogen, and RVVT, (3) to determine if there is correlation between RVVT and PT, and if they vary with AR exposure and 4) to establish baseline health parameters for local RTHs.

\section{Materials And Methods}

\section{$\underline{\text { Animals }}$}

A total of 23 healthy red-tailed hawks (RTH) (Buteo jamaicensis) were recruited from local rehabilitators and outreach programs in Upstate New York (NY) and constituted the control group for establishing baseline ranges for hematological and biochemical analytes and reference ranges for coagulation assays. None of these birds were included in the free ranging RTHs group. Due to the blood volume required for testing, only birds with a body weight greater than $0.80 \mathrm{~kg}$ 
were included in the study. Good health was ascertained based on the animal's history, physical exam, hematological and biochemical profiles. This group of birds had been maintained in captivity for more than 2 months with a controlled rodent food source. These RTHs were classified as "control" and assumed to have no exposure to ARs due to controlled food source and housing conditions. None of the birds in the control group died during the study period.

The clinical cohort consisted of 48 free-ranging red-tailed hawks that presented to the Cornell University Janet L. Swanson Wildlife Hospital (SWH) in Ithaca, NY from June 2016 to May 2018. Due to the volume of blood required to be collected from individual birds on presentation, red-tailed hawks weighing > 0.80 $\mathrm{kg}$ and in condition to sustain the blood collection were enrolled in this study. Intake information including presenting complaint and any history available about each bird was collected from the members of the public presenting the birds. A complete physical examination was performed on each bird including careful assessment for any signs of hemorrhage greater than what would match the extent of trauma seen on exam. When possible, necropsies were also performed on free-ranging red-tailed hawks that either died or were euthanized during the study period. The necropsy information was detailed with gross and histopathological results.

Free-ranging RTHs were classified into groups based on anticoagulant testing results. They were considered "free-ranging AR exposed" if AR was detected in blood and/or liver. "Free-ranging AR not exposed" designated RTHs that had no liver or blood evidence of AR exposure, and "Free-ranging AR unknown exposure" was assigned to RTHs that were blood AR negative but were not necropsied (unknown liver exposure).

\section{Sampling Methods}

To minimize the influence of pre-analytic processing on coagulation test results, blood collection technique was standardized and performed in the same manner for all birds. In free-ranging RTHs, blood was collected within 24 hours of admission to the hospital. Blood sampling was often performed at the rehabilitation facility or permanent housing for control birds. The birds were restrained in left lateral recumbency with the head covered loosely with a towel or hooded to decrease stress. Approximately $3.5 \mathrm{ml}$ of blood was collected from the right jugular vein using a $3 \mathrm{cc}$ syringe and a 22-gauge needle. Gentle pressure was applied to the phlebotomy site until hemostasis was achieved and then birds were released to their carrier or holding pens. The collected blood was immediately aliquoted into (1) one tube containing one-tenth volume sodium citrate anticoagulant (total volume $0.2 \mathrm{~mL}$ citrate $+1.8 \mathrm{ml}$ blood) for whole blood AR testing, (2) an EDTA tube (0.5-1 ml blood) frozen for blood AR analysis, (3) a micro-EDTA tube (0.25ml blood) for hematology analysis, and (4) a third micro-heparin tube $(0.6 \mathrm{ml}$ blood $)$ for biochemistry testing. The citrate and heparin tubes were spun down immediately, and the supernatant plasma collected. Citrated plasma was frozen for later analysis. Heparinized plasma was refrigerated along with whole blood EDTA for submission and analysis within 24 hours for hematology analysis and biochemistry.

If any clinical birds included in the study died spontaneously or were euthanized, $1 \times 1 \mathrm{~cm}$ portions of liver tissue were collected for an anticoagulant screening panel through the Michigan Animal Health Diagnostic Laboratory. A subset of the birds was submitted for complete necropsy when necropsy time was available, and the carcasses were in adequate condition to provide good results. Complete necropsy was performed by the Cornell University Animal Health Diagnostic Laboratory on $5 / 26$ birds that died.

\section{Sample Analyses}

Samples were submitted for complete blood count, biochemical profile, coagulation testing (RVVT, fibrinogen, and PT), and anticoagulant rodenticide analysis.

Complete blood count (hematocrit, white blood cell count, differential analysis, estimated thrombocyte count, white blood cell and red blood cell morphology, total protein via refractometer, plasma appearance, parasite evaluation), and plasma biochemical analysis (sodium, potassium, chloride, uric acid, calcium, phosphate, total protein, glucose, AST, GLDH, CK, bile acids, lipemia, hemolysis, icterus) were performed at the Animal Health Diagnostic Center (AHDC) Ithaca, NY.

Coagulation testing (PT, RVVT, fibrinogen) was performed at the Comparative Coagulation Lab at Cornell University, Ithaca, NY. The PT and RVVT were performed following previously described methods used to monitor anticoagulant effects of ARs in avian (bobwhite and owl) toxicity studies (Rattner et al. 2010, 2012, Rattner, Horak et. al. 2014). Briefly, the PT and RVVT tests were performed using aliquots of citrate plasma diluted in an equal volume of imidazole buffered saline $\left(\mathrm{pH} \mathrm{7.4)}\right.$ ) and warmed to $37^{\circ} \mathrm{C}$ before the addition of a coagulation trigger reagent and calcium. Thromboplastin for the PT assay was prepared in-house from avian (chicken) brain tissue via acetone extraction as previously described. (Rattner et al 2010) For the PT assay, 100 uL of dilute plasma was incubated for 60 seconds, followed by the addition of $200 \mathrm{uL}$ of the thromboplastin reagent containing $25 \mathrm{mM} \mathrm{CaCl}_{2}$. The RVVT assay was configured with a commercially available venom reagent (Russell' viper venom, Sigma, St. Louis, MO). For the RVVT, 100 uL of dilute plasma was incubated with an equal volume venom reagent (prediluted 1:10 in buffered saline) for 30 seconds, followed by the addition of $100 \mathrm{uL} 25 \mathrm{mM} \mathrm{CaCl} 2$. Fibrinogen concentration was measured in undilute plasma using a commercial thrombin reagent (Fibrinogen, Diagnostica Stago, Parsippany NJ) via Clauss method (Clauss 1957) calibrated to the manufacturer's human fibrinogen standard. A single batch of thromboplastin, and single lots of commercial reagents were used for the study. The assays were performed in automated (fibrinogen) or semi-automated (PT, RVVT) coagulation instruments with mechanical endpoint detectors (ST4 and STACompact, Diagnostica Stago, Parsippany, NJ). The upper limit for clot detection for both PT and RVVT was set at 180 seconds. Samples that had not clotted were assigned a clotting time of 180 seconds.

When available, frozen whole blood and liver tissues were submitted for anticoagulant rodenticide analyses to the Michigan State Animal Health Diagnostic Laboratory. The panel included the following first- and second-generation anticoagulants: brodifacoum, bromadiolone, chlorphacinone, difenacoum, difethialone, diphacinone, and warfarin. Lower cutoff for detection for ARs were as follows: $<0.002 \mathrm{ppm}$ for brodifacoum, $<0.07 \mathrm{ppm}$ for difethialone, and $<0.02 \mathrm{ppm}$ for bromadiolone, chlorphacinone, difenacoum, diphacinone, and warfarin in whole blood or liver. 
The distributions of coagulation times (PT, RVVT), and fibrinogen concentrations were assessed for homogeneity of variance (Leven's test) and for normality (Shapiro-Wilk test, normal probability plot, descriptive statistics) and log-transformed when appropriate. If transformations were applied, distributions of logtransformed values were reassessed for homogeneity of variance and normality. Coagulation times (PT, RVVT) and fibrinogen concentrations in free-ranging AR exposed, free-ranging AR not exposed, and control RTHs were compared between groups using one-way analysis of variance (ANOVA). Post hoc comparisons using the Tukey multiple comparison test were made when appropriate. The relationship between PT and RVVT was assessed using Pearson correlation and Deming regression analysis. The relationships between liver brodifacoum concentration and coagulation times (PT, RVVT) were assessed using linear regression. All statistical analyses were performed using GraphPad Prism version 7.05 (GraphPad Software, La Jolla California USA, www.graphpad.com)

\section{Results}

\section{Population Description, Presenting Causes and Hematology and Biochemistry Analyses}

From 2016 to 2018, 72 RTHs were included in this study. The control population included 23 captive RTHs. Collected samples from these birds are summarized in Figure 1a. Blood from 20 out of the 23 control birds was analyzed for hematology and 21 were analyzed for biochemistry These findings are summarized in Tables $1 \mathrm{a}$ and $1 \mathrm{~b}$. Two control RTHs did not have a full biochemistry and three did not have a full hematology due to insufficient sample volume. Results from blood chemistry panel and hematologic analyses in the control birds fell within normal ranges reported for this species (Species 360 ).

The free ranging population included 49 wild birds and the causes for presentation are summarized in Table 2 . Unknown reason for presentation was the leading complaint followed by trauma (including vehicular trauma, trauma of unknown origin, and fractures of unknown origin), and lastly infectious diseases. Full serum biochemistry was obtained in $49 / 49$ birds and full hematology was obtained in $48 / 49$ birds. These findings are summarized in Tables $3 a$ and 3b. One free-ranging RTH was not included in hematology analysis due to insufficient sample volume. Available samples are summarized in Figure 1a. Hematology abnormalities included anemia, leukocytosis, heterophilia, band heterophils, monocytosis, eosinophilia, basophilia, toxic changes, reactive lymphocytes, polychromasia, and the presence of hemoparasites (leukocytozoon, hemoprodius, and plasmodium). Serum biochemistry abnormalities included hyperuricemia, hyperphosphatemia, hypoproteinemia, hyperglycemia, elevated AST, CK, lipemia, hemolysis, and icterus.

Anticoagulant Rodenticide Exposure and Clinical Signs

Twenty-three control birds were examined, and none exhibited clinicopathologic abnormalities consistent with AR toxicity during the study period. Control birds did not have blood submitted for AR analysis.

Results from anticoagulant rodenticide serum and liver residues from free-ranging RTHs are reported in Table 4. Anticoagulant rodenticide exposure was assessed in 35/49 free-ranging birds. AR exposure was assessed in blood only in 19/35 (54\%) birds, in liver only in 1/35 (0.03\%) birds and in both liver and blood in 15/35 (42\%) birds. Liver residue was only assessed in RTHs that died or were euthanized. Eleven of sixteen (68\%) livers tested for AR exposure were positive. Difethialone was found in 1/16 (6\%) liver samples, and brodifacoum was detected in 10/16 (62\%) liver samples. Insufficient sample sizes precluded residue blood testing in all free-ranging RTHs. Available samples were summarized in Figure $1 \mathrm{~b}$. Difethialone was found at a concentration of 0.18 ppm and brodifacoum concentrations ranged from $0.003-0.234 \mathrm{ppm}$. Two of 34 (6\%) RTH assessed for blood rodenticide had brodifacoum in blood with measured concentrations of 0.003 and $0.006 \mathrm{ppm}$. One of these birds had overt bleeding at presentation. No other AR was detected in blood or liver analyses.

\section{Coagulation testing}

Coagulation panels including PT, RVVT, and fibrinogen levels were completed on 22 control birds and 31 free ranging birds. Results of these tests are summarized in Tables 4-6. One control RTH was excluded from coagulation panels due to insufficient sample volume. Six free ranging birds were excluded from this analysis due to clotting of the sample that rendered them unsuitable for coagulation testing and 12 free-ranging RTHs were not analyzed due to insufficient sample size. Of the 31 free-ranging birds for which coagulation panel results were available, RVVT and PT assay clotting times exceeded the upper limit of detection of 180 seconds for 1 bird that was excluded from statistical analysis. The samples included in coagulation test results are summarized in Figure 1c. Median (Interquartile range (IQR); range) for PT, RVVT, and fibrinogen in control, free-ranging RTHs with AR residues detected in the liver, free-ranging RTHs with no AR residues detected in the liver, and free-ranging RTHs with no AR analysis are summarized in Table 6.

There was no evidence of a difference in log-transformed PT between control ( $n=22)$, free-ranging AR exposed ( $n=9)$, and free-ranging AR not exposed RTHs $(n=5)(\operatorname{ANOVA~} F(2,33)=0.08181, p=0.9216)$. There was also no convincing evidence of a difference in log-transformed RVVT between the three groups (ANOVA $F(2,33)=2.128, p=0.1351$ ). However, there was moderate evidence of a difference in log-transformed fibrinogen concentrations between the thee groups (ANOVA $\left.F_{2,33}\right)=6.17, p=0.0053$ ). Post hoc comparisons using the Tukey multiple comparison test indicate that log-transformed fibrinogen concentrations differed between the free-ranging AR exposed birds and both the free-ranging AR not exposed birds $(p-v a l u e=0.0117)$ and the control birds $(p$ $=0.0129)$. However, there was no evidence of a difference between control birds and free-ranging AR not exposed birds ( $p=0.5619)($ Figure 2$)$.

\section{Correlation between PT and RVVT assays}

A total of 22 control birds and 30 free ranging birds were used to assess the relationship between PT and RVVT. Correlation between log-transformed PT and log-transformed RVVT was weak (Pearson's $r=0.6212$ ). The Deming regression also showed strong proportional bias (figure 3 ). The slope of the Deming regression line was $2.715(95 \% \mathrm{Cl} 1.816$ to 3.614$)$ and the $y$-intercept was -2.441 (95\% $\mathrm{Cl}-3.699$ to -1.183$)$.

Brodifacoum levels and coagulation time 
A total of 8 free-ranging AR exposed (liver) RTHs were used to assess the relationship between brodifacoum liver residues and PT or RVVT times. There was no evidence of a linear dependence of PT on brodifacoum liver residues (Test of slope $<>0, F_{1,6}=2.286, p=0.1813$ ), nor was there evidence of a linear dependence of RVVT on brodifacoum liver residues (Test of slope $<>0, F_{1,6}=0.1399, p=.7213$ ) (figure 4).

\section{$\underline{\text { Necropsies }}$}

Twenty-one animals were euthanized and five died. Full necropsy results were available for five free ranging birds summarized in Table 7.

\section{Discussion}

Toxicity secondary to AR exposure is still widely reported in free-ranging raptors despite restrictions on sale and use of certain products and knowledge of its impact on nontarget species such as birds of prey (Anderson et al. 2011, Stone et al. 2003, Kelly et al. 2014, Murray 2011, Kwasnoski et al. 2019, Lambert et al. 2007, Albert et al. 2010, Newton and Wyllie 2002). In 2008 the Environmental Protection Agency prohibited the sale of brodifacoum products in some retail outlets due to the exposure risks to animals and humans, but these products are still widely available online and in agricultural supply stores. Evidence of continued exposure to second generation ARs in free-ranging RTHs in New York State as detected by blood and liver analysis is presented in this study. Second generation rodenticides were the only products identified in hawks in this study. The second generation ARs were introduced in the United States in the 1970s in response to resistance of rodents to first generation rodenticides like warfarin (Buckle et al. 1994). Second generation rodenticides like brodifacoum have a longer half-life in animal tissues longer than first generation products and this increases the possibility that predators like the red-tailed hawks would ingest contaminated prey species and accumulate the toxins in their liver (Anderson et al. 2011, Rattner and Harvey 2020). The toxic effects of acute exposure to rodenticides such as brodifacoum and diphacinone on a variety of bird species have been well established through controlled feeding trials (Rattner et al. 2011, 2012, Rattner and Mastrota 2018, Anderson et al. 2011). Secondary effects such as poor body condition and piloerection have been observed in stoats and RTHs without obvious coagulation issues from AR exposure or contaminated food sources while kestrels have exhibited loss of balance, nonresponsiveness to human approach, subdued behavior, and tan urate deposits with toxic doses of diphacinone (Rattner 2011, Rattner and Mastrota 2018). Feeding trials cannot accurately reflect the true impact secondary exposure may have on a free-ranging bird of the same species that are exposed to other stressors, illnesses, or traumas. No long-term trials have been conducted to assess the secondary effects of ARs on the fitness of wild birds of prey and few studies have investigated the sublethal effects and biological costs of environmental exposure of ARs on wild birds of prey (Vyas et al. 2014, 2017, Kwasnoski et al. 2019).

Two major clinical challenges to diagnosing coagulation deficiencies in birds is the lack of physical exam evidence and the lack of a validated patient side coagulation test. The lack of physical exam changes consistent with AR exposure was well demonstrated in this study with only one bird showing clinical signs of hemorrhage on presentation despite liver residue evidence in several birds. Hemostasis depends on the integrity of the vasculature, the health and number of the platelets, and appropriate activation of secondary coagulation pathways The clotting cascade is the enzymatic process by which secondary coagulation is achieved. The vitamin $\mathrm{K}$ dependent factors of this pathway rely on a vitamin $\mathrm{K}$-dependent carboxylation of glutamic acid residues for them to bind $\mathrm{Ca}^{2+}$ and to become functional. Anticoagulant rodenticides inhibit the vitamin $\mathrm{K}$ epoxide reductase enzyme complex that is needed to recycle vitamin $\mathrm{K}$, resulting in vitamin $\mathrm{K}$ deficiency and the production of inactive coagulation proteins (Harvey 2012). As this is an enzymatic reaction, a certain threshold likely needs to be met before the system is overwhelmed and the body is no longer able to produce functional proteins for the clotting cascade. There were several birds that did not appear to have coagulopathies at presentation, but had measurable stores of anticoagulant in their livers. It is likely that their vitamin $\mathrm{K}$ production was inhibited due to this exposure but the inhibition had not yet reached the threshold needed to impair the vitamin $\mathrm{K}$ dependent coagulation factors in order to see overt hemorrhage. Only one bird in our study, which died shortly after presentation, was found to have overt bleeding on presentation which correlated to subcutaneous and visceral hemorrhage on necropsy and PT/RVVT values of $>180$ seconds, along with a liver brodifacoum liver residue of $0.234 \mathrm{ppm}$. It is likely that RTHs exposed to high levels via acute secondary exposure would die from overt hemorrhage prior to arrival at a wildlife hospital.

In this study, we investigated the use of avian optimized PT and RVVT as clinically relevant diagnostic tests to establish rodenticide exposure in free ranging RTHs. Several tests are available for diagnosing AR exposure in mammals, but these tests are impractical or not applicable to avian patients. A recent study assessing the efficacy of a commercially available point of care device (Coag-Sense ${ }^{\circledR}$ ) used to assess PT in mammals is not suitable for rapid assessment in birds of prey (Dickson 2020). Commercially available toxicological screening for blood rodenticide levels requires a large volume of blood and takes several (35) days before results are available. Prothrombin time (PT) and the activated prothrombin time (aPTT) are the most commonly used coagulation tests for AR exposure in mammals. As a test of the extrinsic, or tissue factor dependent, coagulation pathway, PT measures the function of factors II, VII, and X and clotting time increases if factor VII is depleted. Commercially available PT tests use mammalian thromboplastin as the test reagent. These assays produced unreliable and imprecise results in avian patients, so avian thromboplastin is recommended for PT measurements in birds (Kase, 1978, Morrisey, 2003). PT tests using avian thromboplastin have been developed for research purposes, and in rodenticide feeding trials, PT is a sensitive marker of acute AR coagulopathy in birds of prey (Rattner, et al., 2010, 2011, 2012). However avian-specific PT assays are experimental and are not available to clinical practitioners.

We compared PT and RVVT in RTHs in controlled rehabilitation environments versus free-ranging RTHs presented to a wildlife hospital. The ranges reported here for PT (18-39.7sec) and RVVT (11.5-91.8sec) in control RTHs are higher than previously reported values of free-ranging RTHs admitted to another wildlife hospital (Hindmarch et al. 2019). We report poor correlation between these two tests despite previous reports that have shown prolonged PT and RVVT times with exposure of ARs in controlled environments (Rattner et al. 2011, 2012)._Fibrinogen was included in our coagulation panel in order to rule out nonspecific influences on clotting time or improper collection technique (Rattner et al. 2012). We report fibrinogen values between $58-583 \mathrm{mg} / \mathrm{dL}$. Previous studies have established fibrinogen concentration of greater than $50 \mathrm{mg} / \mathrm{dL}$ as adequate to support clot formation in citrated plasma from several bird species (Hindmarch et al. 2019, Rattner et al. 2010, 2011, 2012). We also investigated the relationship between PT, RVVT, and blood or liver residues of ARs found in exposed free ranging RTHs. Feeding trials in Eastern screech owls and American kestrels report prolonged PT and RVVT within 48 and 96 hr following a 50 mg/kg dose of 
diphacinone and a correlation between dose consumed and liver concentrations (Rattner et al. 2011, 2012). In this study we found no significant relationship between liver AR residue levels and PT or RVVT times in exposed RTHs. Because these RTHs were wild there was no way to control or measure dosage or time from exposure to sampling liver or blood. The doses in oral exposure in controlled feeding trials may be much larger than those RTHs are exposed to from prey species in the wild.

Hepatic tissue has been shown to be a reliable indicator of AR accumulation in birds through both wild caught and controlled studies (Thomas et al. 2011, Hindmarch et al. 2019, Rattner et al. 2012, Newton and Wyllie 2002). ARs were detected in $56 \%$ of the livers samples in this study compared to previous reports ranging from 20-90\% found in deceased wild raptor species (Albert et al. 2010, Lambert et al. 2007, Thomas et al. 2011, Murray 2011, Newton and Wyllie 2002). Brodifacoum and difethialone were the only two ARs detected in RTH liver samples. Hepatic AR residues ranged from $0.003-0.234$ ppm brodifacoum and $0.18 \mathrm{ppm}$ difethialone. These AR levels and types are similar to previous reports of second generation ARs found in free-ranging raptors. (Kelly et al. 2014, Stone et al. 1999, Hindmarch et al. 2019, Albert et al. 2010) In New York State specifically, a previous post-mortem survey detected rodenticide toxins in $49 \%$ of bird carcasses examined, spanning twelve raptor species (Stone, et al., 2003). Prior to that, Stone et al (1999) report rodenticide poisoning as the cause of death in $17 \%$ of examined great horned owls (Bubo virginianus) but only $6 \%$ of red-tailed hawks. Newton and Wyllie (2002) reported it to be the cause of death in $2 \%$ of all barn owl (Tyto alba) carcasses examined over a 15-year period in the United Kingdom (Stone et al. 1999, Newton and Wyllie 2002). This discrepancy in exposure compared to determined cause of death is common and was found in this study as well. Rodenticide was only detected in the blood of two birds in this study (6\%) and only one bird was clinical for AR toxicosis. Exposure studies relying on blood and not tissue samples for AR exposure have reported similarly lower prevalence of ARs compared to tissue studies. Kwasnoski et al report AR exposure in $11 \%$ of serum samples collected from wild red-tailed hawks (Kwasnoski et al. 2019). This lower prevalence is likely because the half-life of these products in blood is much shorter than in tissue like the liver (Anderson et al. 2011). The blood half-life of brodifacoum, the most commonly used AR in rats, is short, and blood levels may no longer be detectable at the time of clinical presentation in many species (Erickson and Urban, 2004). In this study we report postmortem liver AR residues in RTH which are similar to reports in other postmortem surveillance studies (Albert et al. 2010, Lambert et al. 2007, Thomas et al. 2011, Murray 2011, Newton and Wyllie 2002). It is possible that this practice may underestimates actual prevalence of AR exposure due to the shorter half-life of first generation ARs in blood.

The majority of the birds used as controls were housed in rehabilitation settings and included previously wild RTHs that were overwintered prior to release. When selecting our control birds, we made the assumption that they were not exposed to ARs based on the inclusion criteria of having been maintained in captivity for at least 2 months, being fed a controlled food source (laboratory bred rodents), and the lack of potential exposure to rodenticide on the property. It was stipulated that the control birds be free of signs of systemic disease as determined by a normal physical examination, and normal hematology and biochemistry results. The time frame of two months was established early in the study under the assumption that most of the rodenticide exposure would be coming from first generation anticoagulants which have a half-life of hours to days in mammalian tissue and a short elimination time shown in experimentally exposed Screech Owls (Megascops asio) (Fisher et al. 2003, Rattner and Horack et al. 2014). However, as was found in this study, the second generation anticoagulants are still very present in wild RTHs and the limit of two months may mean that some control red-tailed hawks included in this study could have had rodenticide residue in their livers. Classification of RTH as exposed and unknown exposure was based on detection of ARs in blood or liver. We did not submit liver samples for AR analysis in RTH that survived and we acknowledge the fact that their negative blood AR results may be due to the short half-life of circulating AR, thus their classification as "unknown exposure". For this reason, these birds were included in a separate category. In retrospect, a liver biopsy to measure hepatic AR residues on all birds in this study would have improved the interpretation of the data but was beyond the limits of the project. We found that there was no statistical difference between PT and RVVT between control and wild exposed RTH.

In this study, we described the physical findings, baseline bloodwork and necropsy findings when applicable, for red tailed hawks admitted to a wildlife hospital that may have led to the identification of the cause for presentation. Trauma, including vehicular strikes and gunshot wounds, toxicities, starvation, infections, parasitic infestations, and orphaning are the most common reasons for RTH admissions to a wildlife hospital and known prior history are usually limited (Harris and Sleeman 2007, Molina-Lopez et al. 2011, Komnenou et al. 2005, Albert et al. 2010). In our study, RTHs that were seen being hit by a vehicle or were found with acute trauma on the side of the road were considered cases of vehicular trauma. Some of the birds with fractures of unknown origin were found by roads but had chronic wounds so this relationship was suspected but could not be confirmed. Birds with trauma of unknown origin were found in various places including yards, fields, or buildings and the original trauma could not be confirmed as vehicular. Three birds were confirmed to have Aspergillus sp. infections. All three birds with Aspergillus sp. infections were found to have other comorbidities. One had bilateral uveitis and anemia, the second had conjunctivitis and stomatitis, and the third had central neurologic lesions and was suspected to be a case of vehicular head trauma. The condition of fourteen of the hawks was classified as unknown as the presentation and history did not reveal a specific presenting cause. Infectious diseases were overrepresented in necropsies performed in this study but RTHs presenting with overt trauma such as head trauma or fractures were not submitted for full necropsy due to funding constraints.

Hematologic and biochemical analysis were performed on control and wild RTHs in this study. Control birds had values within normal reference range expected for this species (Species 360). Changes to blood work found in wild RTHs were reflective of common causes of presentation previously reported for wild birds to wildlife hospitals including evidence of trauma (AST and CK elevation) evidence of infection (leukocytosis, heterophilia, band heterophils, monocytosis, eosinophilia, basophilia, toxic changes, reactive lymphocytes, polychromasia, and the presence of hemoparasites). Four of the wild RTHs were found to have PCV $<=22 \%$ on presentation. Two of these were found to have AR exposure, one in blood and one in liver. One of the four birds was not tested for AR due to loss of sample. One of these AR exposed birds was presented for pelvic limb paresis as suspected hit by car trauma, and the other was presented as an unknown trauma with an elbow luxation. AR exposure should be considered a differential in anemic RTHs regardless of the presenting complaint. 
The total population of wild-caught RTHs in this study were presented to the hospital by the general public, DEC officers, or wildlife rehabilitators which meant that the number of wild caught RTHs was dependent on external sources. The birds had to weigh more than $0.80 \mathrm{~kg}$ and needed to be stable enough for blood collection upon admittance to the hospital. Many RTHs presented underweight and severely dehydrated, excluding them from the study. Despite our efforts to select individuals that were stable, hypovolemia may have complicated our ability to obtain proper samples for analysis. The right jugular vein was used as the preferred vessel for collecting a large volume of blood. If the bird struggled, or multiple venipuncture were required, it was very likely that pre-analytical artifact from clotting factor activation rendered the sample invalid. Eight samples were excluded in this study due to visible clots prior to PT and RVVT analysis.

\section{Conclusion}

Birds of prey are exposed to vitamin K-antagonist anticoagulant rodenticides (ARs) through consumption of intoxicated rodent prey. While acute, high-dose rodenticide exposure causes severe and typically fatal hemorrhage in raptors, the cumulative effect of repeated, low-level exposure is unknown. PT and RVVT were not found to correlate in our control group and no correlation was found between liver AR residue and either coagulation test in this study. PT and RVVT were not found to be sensitive markers of AR exposure in the RTH presented to the wildlife hospital but the widespread exposure to secondary ARs continues to be a problem in this free-ranging population. Without a sensitive test to detect early subclinical coagulopathies, AR toxicity in birds remains underdiagnosed and untreated. The data from this study can be utilized by governmental agencies to determine the impact on free ranging wildlife and help bolster efforts to restrict the use of these pesticides in the environment. This study also provides a foundation for future research on the use of PT or RVVT in a clinical setting to monitor patients being treated for AR toxicity and the possible use of liver biopsies to study the subclinical effects of AR exposure on long term fitness of wild birds of prey.

\section{Declarations}

Acknowledgements: The authors would like to thank the staff of the Janet L. Swanson Wildlife Hospital as well as the staff in the Wildlife Health Lab and Comparative Coagulation Lab who assisted with obtaining and processing the samples used in this study. The authors would also like to thank Tatiana Weisbrod for her invaluable help in establishing this project.

Funding- This study was funded by the Wiederhold Foundation at the Cornell University College of Veterinary Medicine

Conflicts of interest/Competing interests- The authors declare that there was no conflict of interest or competing interests.

Availability of data and material- Not applicable

Code availability- Not applicable

Ethics approval-This study was approved by the Cornell University Animal Care and Use Committee

Consent to participate- Not applicable

Consent for publication- This paper and all its contents were review and approved for publication by all contributing authors

\section{References}

1. Albert CA, Wilson LK, Mineau P, Trudeau S, Elliott JE (2010) Anticoagulant rodenticides in three owl species from Western Canada, 1988-2003. Archives of Environmental Contamination and Toxicology 58(2):451-459

2. Anderson B, Borges S, Barber K, Hartless C, Housenger J, Mastrota N, Odenkirchen E, Riley E, Wagman M (2011) Risks of Non-Compliant Rodentiides to Nontarget Wildlife. USEPA Office of Chemical Safety and Pollution Prevention, pp 1-183

3. Borst GHA, Counotte GHM (2002) Shortfalls using Second-generation Anticoagulant Rodenticides. J Zoo Wild Med 33(1):85

4. Buckle AP, Prescott CV, Ward KJ (1994) Resistance to the first and second generation anticoagulant rodenticides-a new perspective. Proceedings of the Vertebrate Pest Conference. 16(6)

5. Buckle AP, Prescott C (2018) Anticoagulants and risk mitigation.. In: In: van den Brink N, Elliott JE, Shore RF, Rattner BA (eds) Anticoagulant Rodenticides and Wildlife. Springer International Publishing, Cham, Switzerland, pp 319-355

6. Clauss A (1957) Gerinnungsphysiologische Schnellmethode zur Bestimmung des Fibrinogens. Acta Haematol, 17; Pp. 237-246

7. Dutto M, Di Domenico D, Rubbiani M (2018) Use of anticoagulant rodenticides in outdoor urban areas: Considerations and proposals for the protection of public health and non-target species. Annali di Igiene 30(1):44-50

8. DuVall MD, Murphy MJ, Ray AC, Reagor JC (1989) Case studies on second-generation anticoagulant rodenticide toxicities in nontarget species. J Vet Diagn Invest 1:66-68

9. Elliott JE, Hindmarch S, Albert CA, Emery J, Mineau P, Maisonneuve F (2014) Exposure pathways of anticoagulant rodenticides to nontarget wildlife. Environmental Monitoring and Assessment 186(2):895-906

10. Elmeros M, Bossi R, Christensen TK, Kjær LJ, Lassen P, Topping CJ (2019) Exposure of non-target small mammals to anticoagulant rodenticide during chemical rodent control operations. Environmental Science and Pollution Research 26(6):6133-6140

11. Erickson W, Urban D (2004) Potential risks of nine rodenticides to birds and nontarget mammals: a comparative approach. Environmental Protection Agency

Page $7 / 22$ 
12. Fisher P, O'Connor C, Wright G, Eason CT (2003) Rersistence of four anticoagulant rodenticides in the livers of laboratory rats. Department of Conservation Science Internal Series 139,New Zealand

13. Harris MC, Sleeman JM (2007) Morbidity and mortality of bald eagles (Haliaeetus leucocephalus) and peregrine falcons (Falco peregrinus) admitted to the Wildlife Center of Virginia, 1993-2003. J Zoo Wild Med 38(1):62-66

14. Harvey JW (2012) Evaluation of Hemostasis. Veterinary Hematology. 191-233

15. Hindmarch S, Rattner BA, Elliott JE (2019) Use of blood clotting assays to assess potential anticoagulant rodenticide exposure and effects in free-ranging birds of prey. Science of the Total Environment 657:1205-1216

16. Hydock KL, Declementi C, Fish PH (2017) Second-generation anticoagulant rodenticide poisoning in a captive andean condor (Vultur gryphus). Journal of Avian Medicine and Surgery 31(3):256-261

17. Jackson WB, Kaukeinen DE (1972) The problem of anticoagulant rodenticide resistance in the United States. In: Proceedings of the Vertebrate Pest Conference. pp.142-148

18. Jacob J, Buckle AP (2018) Use of anticoagulant rodenticides in different applications around the world.. In: In: van den Brink N, Elliott JE, Shore RF, Rattner BA (eds) Anticoagulant Rodenticides and Wildlife. Springer International Publishing, Cham, Switzerland, pp 11-44

19. Kase F (1978) The effect of homo- and heterologous thromboplastins on plasmas of man, seven mammalian and two avian species. Comp Biochem Physiol 61:65-68

20. Kelly TR, Poppenga RH, Woods LA, Hernandez YZ, Boyce WM, Samaniego FJ, Torres SG, Johnson CK (2014) Causes of mortality and unintentional poisoning in predatory and scavenging birds in California.Veterinary Record Open.1(1)

21. Kohn B, Weingart C, Giger U (2003) Haemorrhage in seven cats with suspected anticoagulant rodenticide intoxication. Journal of Feline Medicine and Surgery 5(5):295-304

22. Komnenou AT, Georgopoulou I, Savvas I, Dessiris A (2005) A retrospective study of presentation, treatment, and outcome of free-ranging raptors in Greece (1997-2000). Journal of Zoo and Wildlife Medicine 36(2):222-228

23. Kwasnoski LA, Dudus KA, Fish AM, Abernathy EV, Briggs CW (2019) Examining Sublethal Effects of Anticoagulant Rodenticides on Haemosporidian Parasitemia and Body Condition in Migratory Red-Tailed Hawks. Journal of Raptor Research 53(4):402-409

24. Lambert O, Pouliquen H, Larhantec M, Thorin C, L'Hostis M (2007) Exposure of raptors and waterbirds to anticoagulant rodenticides (difenacoum, bromadiolone, coumatetralyl, coumafen, brodifacoum): Epidemiological survey in Loire Atlantique (France). Bulletin of Environmental Contamination and Toxicology 79(1):91-94

25. Lohr MT, Davis RA (2018) Anticoagulant rodenticide use, non-target impacts and regulation: A case study from Australia. Sci Total Environ 634:13721384

26. López-Perea L, Mateo R (2018) Secondary exposure of anticoagulant rodenticides and effects in predators.. In: In: van den Brink N, Elliott JE, Shore RF, Rattner BA (eds) Anticoagulant Rodenticides and Wildlife. Springer International Publishing, Cham, Switzerland, pp 159-193

27. Memmott K, Murray M, Rutberg A (2017) Use of anticoagulant rodenticides by pest management professionals in Massachusetts. USA Ecotoxicology 26(1):90-96

28. Molina-Lopez RA, Casal J, Darwich L (2011) Causes of Morbidity in Wild Raptor Populations Admitted to a Wildlife Rehabilitation Center in Spain from 1995-2007: A Long Term Retrospective Study.PLoS ONE6(9)

29. Morrisey JK, Paul-Murphy J, Fialkowski JP, Hart A, Darien BJ (2003) Estimation of Prothrombin Times of Hipaniolan Amazon pParrots (Amazona ventralis) and Umbrella Cockatoos (Cacatua alba). Journal of Avian Medicine and Surgery 17(2):72-77

30. Murphy MJ, Gerkin D (1989) The anticoagulant rodenticides. Current Veterinary Therapy X. Ed. Kirk, RW. WB Saunders, Philadelphia, pp $143-146$

31. Murray M (2011) Anticoagulant rodenticide exposure and toxicosis in four species of birds of prey presented to a wildlife clinic in Massachusetts, 20062010. Journal of Zoo and Wildlife Medicine 42(1):88-97

32. Murray M (2020) Continued Anticoagulant Rodenticide Exposure of Red-tailed Hawks (Buteo jamaicensis) in the Northeastern United States with an Evaluation of Serum for Biomonitoring. Environmental Toxicology and Chemistry 39(11):2325-2335

33. Newton I, Wyllie I (2002) Rodenticides in British Barn Owls (Tyto alba). Ecology and Conservation of Owls. pp. 287-295

34. Rattner BA, Horak KE, Warner SE, Day DD, Johnston JJ (2010) Comparative Toxicity of Diphacinone to Northern Bobwhite (Colinus virginianus) and American Kestrels (Falco sparverius). Proceedings of the Vertebrate Pest Conference. 24

35. Rattner BA, Horak KE, Warner SE, Day, Daniel D, Meteyer CU, Volker SF, Eisemann JD, Johnston JJ (2011) Acute toxicity, histopathology, and coagulopathy in american kestrels (falco sparverius) following administration of the rodenticide diphacinone. Environ Toxicol Chem 30(5):1213-1222

36. Rattner BA, Horak KE, Lazarus RS, Eisenreich KM, Meteyer CU, Volker SF, Campton CM, Eisemann JD, Johnston JJ (2012) Assessment of toxicity and potential risk of the anticoagulant rodenticide diphacinone using Eastern screech-owls (Megascops asio). Ecotoxicology 21(3):832-846

37. Rattner BA, Horak KE, Lazarus RS, Goldade DA, Johnston JJ (2014) Toxicokinetics and coagulopathy threshold of the rodenticide diphacinone in eastern screech-owls (Megascops asio). Environmental Toxicology and Chemistry 33(1):74-81

38. Rattner BA, Lazarus RS, Elliott JE, Shore RF, Van Den Brink N (2014) Adverse outcome pathway and risks of anticoagulant rodenticides to predatory wildlife. Environmental Science and Technology 48(15):8433-8445. doi:10.1021/es501740n

39. Rattner BA, Mastrota FN (2018) Anticoagulant Rodenticide Toxicity to Non-target Wildlife Under Controlled Exposure Conditions.. In: In: van den Brink N, Elliott JE, Shore RF, Rattner BA (eds) Anticoagulant Rodenticides and Wildlife. Springer International Publishing, Cham, Switzerland, pp 45-86 
40. Rattner BA, Harvey JJ (2020) Challenges in the interpretation of anticoagulant rodenticide residues and toxicity in predatory and scavenging birds. Pest Management Science

41. Ruiz-Suarez N, Henriquez-Hernandez LA, Valeron PF, Boada LD, Zumbado M, Camacho M, Almeida-Gonzalez M, Luzardo OP (2014) Science of the Total Environment. 485-486:371-376

42. Seljetun KO, Sandvik M, Vindenes V, Eliassen E, Oiestad EL, Madslien K, Moe L (2020) Comparison of anticoagulant rodenticide concentrations in liver and feces from apparently healthy red foxes. J Vet Diagn Invest 32(4):560-564

43. Slankard KG, Gaskill CL, Cassone LM, Rhoden CM (2019) Changes in detected anticoagulant rodenticide exposure in barn owls (Tyto alba) in Kentucky, USA, in 2012-16. Journal of Wildlife Diseases 55(2):432-437

44. Species 360 [Internet]. Zoological information management system: expected test results. Red Tailed Hawk (Buteo jamaicensis). available from https://www.species360.org/Main.aspx

45. Stansley W, Cummings M, Vudathala D, Murphy LA (2014) Anticoagulant rodenticides in red-tailed hawks, Buteo jamaicensis, and great horned owls, Bubo virginianus, from New Jersey, USA, 2008-2010. Bulletin of Environmental Contamination and Toxicology 92(1):6-9

46. Stone WB, Okoniewski JC, Stedelin JR (1999) Poisoning of Wildlife with Anticoagulant Rodenticides in New York. J Wildl Dis 35(2):187-193

47. Stone WB, Okoniewski JC, Stedelin JR (2003) Anticoagulant rodenticides and raptors: Recent findings from New York, 1998-2001. Bulletin of Environmental Contamination and Toxicology 70(1):34-40

48. Thomas PJ, Mineau P, Shore RF, Champoux L, Martin PA, Wilson LK, Fitzgerald G, Elliott JE (2011) Second generation anticoagulant rodenticides in predatory birds: Probabilistic characterisation of toxic liver concentrations and implications for predatory bird populations in Canada. Environment International 37(5):914-920. http://dx.doi.org/10.1016/j.envint.2011.03.010.. doi:10.1016/j.envint.2011.03.010

49. USEPA Regulating rodenticides (2017) http://www.epa.gov/rodenticides.Last updated April

50. Vandenbroucke V, Bousquet-Melou A, De Backer P, Croubels S (2008) Pharmacokinetics of eight anticoagulant rodenticides in mice after single oral administration. Journal of Veterinary Pharmacology and Therapeutics 31(5):437-445. doi:10.1111/j.1365-2885.2008.00979.x

51. Vyas NB, Lockhart JM, Rattner BA, Kuncir F (2014) Coagulopathy and survival of ret-tailed hawks following exposure to the anticoagulant rodenticide Rozol®. Society of Environmental Toxicology and Chemistry-North America 35th Annual Meeting. MP043

52. Vyas NB, Kuncir F, Clinton CC (2017) Influence of poisoned prey on foraging behavior of ferruginous hawks. Am Midl Nat 177:75-83

53. Witmer GW (2018) Perspectives on existing and potential new alternatives to anticoagulant rodenticides and the implications for integrated pest management.. In: In: van den Brink N, Elliott JE, Shore RF, Rattner BA (eds) Anticoagulant Rodenticides and Wildlife. Springer International Publishing, Cham, Switzerland, pp 357-378

\section{Tables}

Table 1a. Hematology values for 21 control red-tailed hawks included in final analysis. 


\begin{tabular}{|c|c|c|c|c|c|c|c|c|c|c|c|}
\hline $\begin{array}{l}\text { Hawk } \\
\text { study } \\
\#\end{array}$ & $\begin{array}{l}\text { PCV } \\
(\%)\end{array}$ & $\begin{array}{l}\text { WBC } \\
\text { (thou/uL) }\end{array}$ & $\begin{array}{l}\text { Seg. } \\
\text { Heterophils } \\
\text { (thou/uL) }\end{array}$ & $\begin{array}{l}\text { Bands } \\
\text { (thou/uL) }\end{array}$ & $\begin{array}{l}\text { Lymphocytes } \\
\text { (thou/uL) }\end{array}$ & $\begin{array}{l}\text { Monocytes } \\
\text { (thou/uL) }\end{array}$ & $\begin{array}{l}\text { Eosinophils } \\
\text { (thou/uL) }\end{array}$ & $\begin{array}{l}\text { Basophils } \\
\text { (thou/uL) }\end{array}$ & $\begin{array}{l}\text { Platelet } \\
\text { Smear } \\
\text { Estimation }\end{array}$ & $\begin{array}{l}\text { Plasma } \\
\text { Appearance }\end{array}$ & $\begin{array}{l}\text { TP- } \\
\text { Ref } \\
(\mathrm{g} / \mathrm{dL})\end{array}$ \\
\hline $\mathrm{C} 1$ & 35 & 12.9 & 6.5 & 0 & 4.8 & 0.1 & 1.5 & 0 & $\begin{array}{l}\text { Adequate } \\
\text { (Some } \\
\text { clumps) }\end{array}$ & $\begin{array}{l}\text { Slight } \\
\text { Lipemia }\end{array}$ & 4.3 \\
\hline $\mathrm{C} 2$ & 45 & 8.9 & 5.7 & 0 & 1.9 & 0.7 & 0.6 & 0 & Adequate & Normal & 5 \\
\hline C3 & 35 & 13 & 6.8 & 0 & 3.3 & 1.8 & 1 & 0.1 & Adequate & Normal & 4.5 \\
\hline C4 & 38 & 7.6 & 3.2 & 0 & 3.1 & 0.6 & 0.6 & 0.1 & Adequate & Normal & 4.1 \\
\hline C5 & 42 & 4.8 & 2.2 & 0.1 & 0.1 & 0.9 & 1.2 & 0.4 & Adequate & Normal & 3.9 \\
\hline $\mathrm{C} 6$ & 42 & 8 & 5 & 0 & 0.2 & 1 & 1.6 & 0.2 & Adequate & Normal & 4.9 \\
\hline C7 & 43 & 9.3 & 5.4 & 0 & 0.5 & 0.7 & 1.9 & 0.9 & Adequate & Normal & 5 \\
\hline C8 & 43 & 7.4 & 2.7 & 0 & 2.4 & 0.9 & 1.3 & 0.1 & Adequate & $\begin{array}{l}\text { Slight } \\
\text { Hemolysis }\end{array}$ & 4.5 \\
\hline C9 & 43 & 16 & 9.6 & 0 & 4.6 & 0.3 & 1.4 & 0 & Adequate & Normal & 4.9 \\
\hline C10 & & $5-8$ & $66 \%$ & $0 \%$ & $15 \%$ & $9 \%$ & $8 \%$ & $2 \%$ & Adequate & & \\
\hline C11 & 46 & 6.6 & 3.6 & 0 & 1.3 & 1.1 & 0.5 & 0.2 & Adequate & Normal & 4.6 \\
\hline C12 & & $15-20$ & $46 \%$ & 0 & $26 \%$ & $13 \%$ & $14 \%$ & $1 \%$ & Adequate & & \\
\hline C13 & 33 & 24.5 & 6.6 & 0 & 3.4 & 2.7 & 10.8 & 1 & Adequate & normal & 4.8 \\
\hline C14 & 46 & 9.8 & 5.1 & 0 & 1 & 1 & 1.9 & 0.9 & adequate & $\begin{array}{l}\text { hemolysis } \\
\text { slight }\end{array}$ & 4.5 \\
\hline C16 & 43 & 13.5 & 8.5 & 0 & 4.2 & 0.1 & 0.5 & 0.1 & Adequate & $\begin{array}{l}\text { lipemia- } \\
\text { slight }\end{array}$ & 5.2 \\
\hline C17 & 40 & 14.3 & 7.6 & 0.1 & 1.7 & 0.7 & 3.3 & 0.9 & Adequate & Normal & 4.2 \\
\hline C18 & 42 & 10.4 & 8.7 & 0 & 0.1 & 0.4 & 0.6 & 0.5 & Adequate & $\begin{array}{l}\text { lipemia- } \\
\text { moderate }\end{array}$ & $\begin{array}{l}\text { not } \\
\text { done }\end{array}$ \\
\hline C19 & 45 & 9.6 & 6.4 & 0 & 0.4 & 1.2 & 1 & 0.7 & Adequate & Normal & 5.1 \\
\hline $\mathrm{C} 20$ & 53 & 18.8 & 8.3 & 0 & 3.9 & 2.1 & 3.4 & 1.1 & Adequate & Normal & 5.9 \\
\hline C21 & 44 & 15.1 & 9.4 & 0 & 3.9 & 0.5 & 1.4 & 0 & Adequate & Normal & 5.7 \\
\hline
\end{tabular}

Table 1b. Serum biochemistry values for 21 control red-tailed hawks. 


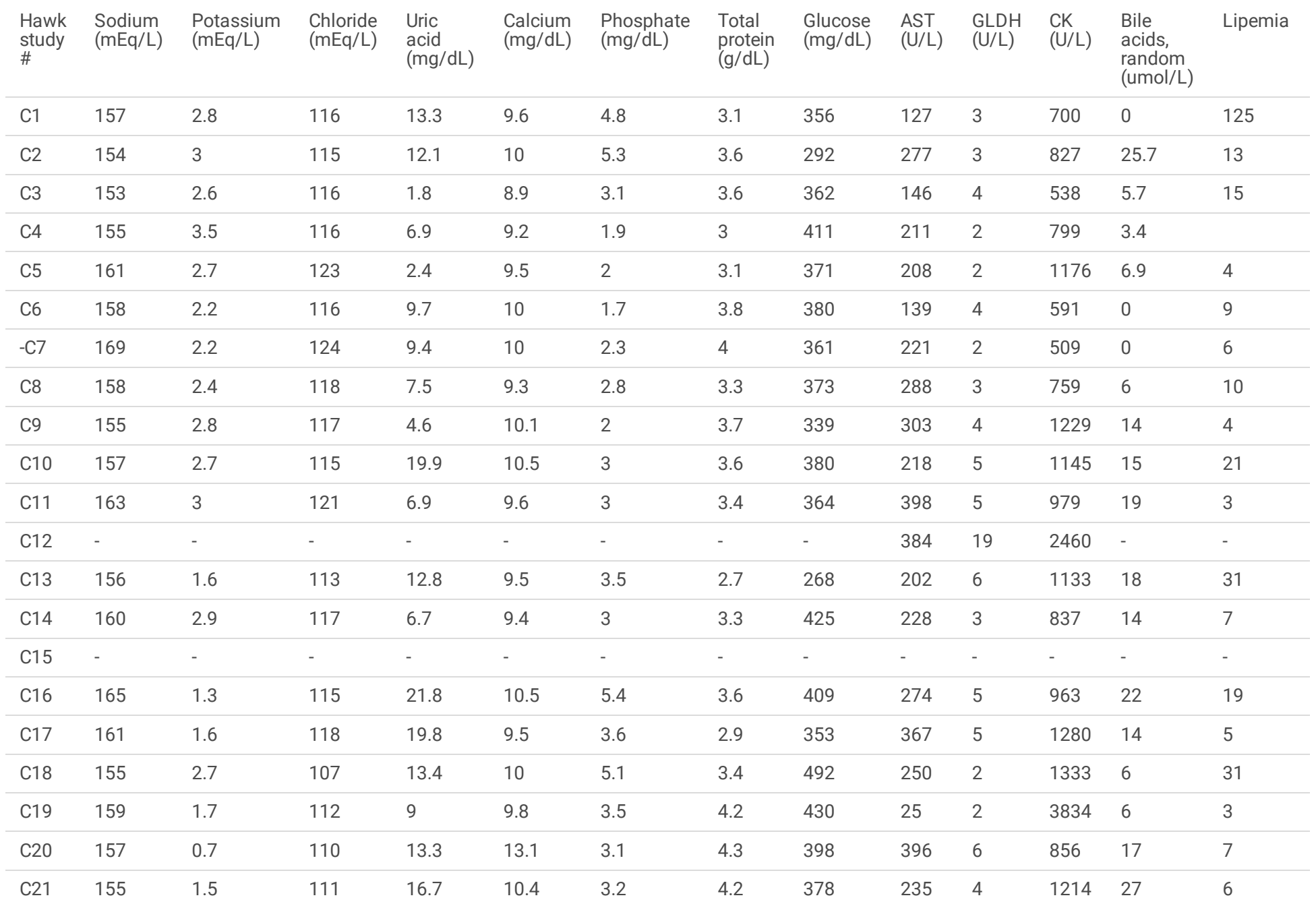

Table 2. Presenting complaints for free-ranging red-tailed hawks presenting to a wildlife hospital in New York.

\begin{tabular}{ll} 
Reason for Presentation & Number of cases \\
\hline Fractures of unknown origin & 8 \\
\hline Presumptive vehicular trauma & 13 \\
\hline Infectious disease & 5 \\
\hline Trauma of unknown origin & 11 \\
\hline Unknown & 14 \\
\hline Total cases & 51
\end{tabular}

Table 3a. Hematology values for the final 49 free ranging red tailed hawks included in the study analysis. (*) indicates estimated WBC count based on blood smear analysis. NSF indicates no significant findings. 


\begin{tabular}{|c|c|c|c|c|c|c|c|c|c|c|c|c|}
\hline $\begin{array}{l}\text { Hawk } \\
\text { study } \\
\#\end{array}$ & $\begin{array}{l}\text { PCV } \\
(\%)\end{array}$ & $\begin{array}{l}\text { WBC } \\
\text { (thou/ul) }\end{array}$ & $\begin{array}{l}\text { Seg. } \\
\text { Heterophil } \\
\text { (thou/ul) }\end{array}$ & $\begin{array}{l}\text { Band } \\
\text { (thou/ul) }\end{array}$ & $\begin{array}{l}\text { Lymphocyte } \\
\text { (thou/ul) }\end{array}$ & $\begin{array}{l}\text { Monocyte } \\
\text { (thou/ul) }\end{array}$ & $\begin{array}{l}\text { Eosinophil } \\
\text { (thou/ul) }\end{array}$ & $\begin{array}{l}\text { Basophil } \\
\text { (thou/ul) }\end{array}$ & $\begin{array}{l}\text { Platelet } \\
\text { estimate }\end{array}$ & $\begin{array}{l}\text { Plasma } \\
\text { appearance }\end{array}$ & $\mathrm{TP}(\mathrm{g} / \mathrm{dl})$ & WBC \\
\hline 1 & 31 & 21 & 8.6 & 0 & 5.3 & 2.5 & 4.6 & 0 & Adequate & Normal & 4 & NSF \\
\hline 2 & 41 & 23.8 & 11.9 & 0 & 3.3 & 7.1 & 1.4 & 0 & $\begin{array}{l}\text { Adequate } \\
\text { (some } \\
\text { clumps) }\end{array}$ & Normal & 4.3 & NSF \\
\hline 3 & 55 & 29 & 16 & 0 & 0.9 & 1.2 & 5.2 & 0 & Adequate & $\begin{array}{l}\text { Slight } \\
\text { Hemolysis }\end{array}$ & 5.3 & NSF \\
\hline 4 & 19 & $20-30 *$ & $51 \%$ & $0 \%$ & $27 \%$ & $5 \%$ & $16 \%$ & $1 \%$ & Adequate & Normal & & $\begin{array}{l}\text { Few F } \\
\text { Lymp }\end{array}$ \\
\hline 5 & 34 & 23.1 & 15.9 & 0.5 & 0.2 & 0.9 & 5.1 & 0.5 & Adequate & Normal & 4.3 & NSF \\
\hline 6 & 18 & 7.4 & 5.8 & 0.7 & 0.1 & 0.6 & 0.1 & 0 & Adequate & Normal & $<2.5$ & $\begin{array}{l}\text { Mild } 1 \\
\text { chan! } \\
\text { neutr } \\
\text { few } \\
\text { smuc } \\
\text { cells }\end{array}$ \\
\hline 7 & 35 & 15.8 & 10.3 & 1.7 & 0.5 & 0.9 & 2.2 & 0.2 & $\begin{array}{l}\text { Adequate } \\
\text { (Some } \\
\text { clumps) }\end{array}$ & Normal & 3.8 & $\begin{array}{l}\text { Mild } 1 \\
\text { chan! } \\
\text { neutr }\end{array}$ \\
\hline 8 & 28 & 9.2 & 5.1 & 0.3 & 2.6 & 0.2 & 1.1 & 0 & Adequate & $\begin{array}{l}\text { lipemia } \\
\text { slight } \\
\text { hemolysis } \\
\text { slight }\end{array}$ & not done & NSF \\
\hline 9 & 22 & 30.3 & 7 & 18.2 & 1.2 & 1.2 & 1.8 & 0.9 & Adequate & $\begin{array}{l}\text { Slight } \\
\text { Icterus }\end{array}$ & 4.2 & $\begin{array}{l}\text { Mark } \\
\text { chan! } \\
\text { neutr } \\
\text { Few r } \\
\text { lympl }\end{array}$ \\
\hline 10 & 35 & $10-15^{\star}$ & $45 \%$ & $0 \%$ & $39 \%$ & $5 \%$ & $11 \%$ & $0 \%$ & Adequate & Normal & 4.8 & NSF \\
\hline 11 & 38 & 14.1 & 7.9 & 0.3 & 1.6 & 1.1 & 2.3 & 1 & Adequate & Normal & 4.4 & NSF \\
\hline 12 & 35 & 12.4 & 6.7 & 4.1 & 0.4 & 0 & 0.7 & 0.5 & Adequate & Normal & 4.6 & NSF \\
\hline 13 & 42 & 16.7 & 11.4 & 0.3 & 1 & 0.7 & 2.3 & 1 & Adequate & $\begin{array}{l}\text { Slight } \\
\text { Hemolysis }\end{array}$ & 4.8 & NSF \\
\hline 14 & 38 & 18.3 & 0.5 & 8.2 & 2.4 & 6.6 & 0.5 & 0 & Adequate & $\begin{array}{l}\text { Slight } \\
\text { Hemolysis }\end{array}$ & 5.6 & $\begin{array}{l}\text { Toxic } \\
\text { Chan } \\
\text { neutr } \\
\text { Mark }\end{array}$ \\
\hline 15 & 34 & 6.4 & 3.4 & 0.5 & 0.3 & 0.7 & 1.4 & 0.1 & Adequate & $\begin{array}{l}\text { Slight } \\
\text { Hemolysis }\end{array}$ & 4.2 & $\begin{array}{l}\text { Toxic } \\
\text { Chan } \\
\text { neutr } \\
\text { Mild }\end{array}$ \\
\hline 16 & 32 & 16.4 & 7.5 & 3.3 & 0.8 & 2.8 & 1.8 & 0.2 & Adequate & $\begin{array}{l}\text { Slight } \\
\text { Hemolysis }\end{array}$ & 5.1 & smuc \\
\hline 17 & - & $40-60^{*}$ & $42 \%$ & $2 \%$ & $29 \%$ & $10 \%$ & $15 \%$ & $2 \%$ & Increased & & & $\begin{array}{l}\text { React } \\
\text { lympl }\end{array}$ \\
\hline 18 & 36 & 15.5 & 11.5 & 0.3 & 2.3 & 0.9 & 0.5 & 0 & Adequate & Normal & 4.3 & NSF \\
\hline 19 & 29 & 28.7 & 14.4 & 0 & 1.7 & 0.9 & 10.9 & 0.9 & Adequate & normal & 4.5 & NSF \\
\hline 20 & 39 & 11.1 & 8.8 & 0 & 0.2 & 0.6 & 1.3 & 0.2 & Adequate & $\begin{array}{l}\text { lipemia } \\
\text { slight }\end{array}$ & 5.6 & smuc \\
\hline 21 & 31 & 8.5 & 5.9 & 0.4 & 1.2 & 0.2 & 0.4 & 0.3 & adequate & Normal & $<2.5$ & NSF \\
\hline 22 & 36 & 20.1 & 13.9 & 0 & 3.4 & 0.6 & 1.8 & 0.4 & Adequate & normal & 5.3 & NSF \\
\hline
\end{tabular}




$\begin{array}{lllllllllllll}23 & 30 & 2.1 & 0.7 & 0.7 & 0.4 & 0 & 0.3 & 0 & \text { Adequate } & \text { Normal }\end{array}$

\begin{tabular}{|c|c|c|c|c|c|c|c|c|c|c|c|c|}
\hline 24 & 39 & 12.1 & 5.2 & 0.5 & 2.3 & 0.8 & 3.3 & 0 & Adequate & Normal & 5.4 & Norm \\
\hline 25 & 31 & 8.1 & 3.3 & 1.1 & 0.2 & 1.5 & 1.9 & 0.1 & Adequate & Normal & 4.1 & $\begin{array}{l}\text { Mild } 1 \\
\text { chan! } \\
\text { neutr }\end{array}$ \\
\hline 26 & 35 & 3.6 & 3 & 0 & 0.4 & 0 & 0.1 & 0 & Adequate & Normal & 3.2 & NSF \\
\hline
\end{tabular}

\begin{tabular}{|c|c|c|c|c|c|c|c|c|c|c|c|}
\hline 27 & 39 & 8.6 & 5.8 & 0 & 0.2 & 0.9 & 1.5 & 0.3 & Adequate & normal & 5.1 \\
\hline
\end{tabular}

\begin{tabular}{rrrrrrrrrrrrr}
28 & 24 & 23 & 16.3 & 0 & 0.5 & 1.2 & 4.1 & 0.9 & Adequate normal & 4 & NSF \\
\hline 29 & 22 & 9.3 & 6 & 0 & 2.5 & 0 & 0.6 & 0.3 & Adequate normal & 3.5 & NSF
\end{tabular}

\begin{tabular}{|c|c|c|c|c|c|c|c|c|c|c|c|c|}
\hline 30 & 37 & 35 & 26.6 & 0 & 1.8 & 3.8 & 2.1 & 0.7 & Adequate & icterus- & 5.5 & NSF \\
\hline
\end{tabular}

$\begin{array}{lllllllllll}31 & 34 & 6.4 & 3.6 & 1.2 & 0.8 & 0.3 & 0.4 & 0.1 & \text { Adequate normal } & \begin{array}{l}\text { Mild } 1 \\ \text { chan! } \\ \text { neutri }\end{array}\end{array}$

$\begin{array}{lllllllllll}32 & 33 & 56.2 & 39.9 & 11.2 & 0.6 & 3.9 & 0.6 & 0 & \text { Adequate } & \text { Normal }\end{array}$

$\begin{array}{ll}\text { in } & \\ \text { mild } & \end{array}$
mild,

smuc cellsreacti lympl

$\begin{array}{lllllllllll}33 & 28 & 12.3 & 10.3 & 0 & 0.1 & 0.4 & 0.9 & 0.6 & \text { Adequate Normal }\end{array}$

\begin{tabular}{lllllllllll}
\hline 34 & 25 & 70.8 & 28.3 & 24.8 & 3.5 & 9.9 & 4.2 & 0 & Adequate normal
\end{tabular}

\begin{tabular}{l} 
in $\begin{array}{l}\text { neutr } \\
\text { mod } \epsilon\end{array}$ \\
\hline
\end{tabular}

$\begin{array}{llllllllll}35 & 36 & 54.9 & 23.6 & 26.9 & 0 & 2.7 & 0.5 & 1.1 & \text { Adequate normal }\end{array}$

\begin{tabular}{|c|c|c|c|c|c|c|c|c|c|c|c|c|}
\hline 36 & 35 & 16.2 & 12.3 & 0 & 0.3 & 1 & 2.1 & 0.5 & Adequate & normal & 3.4 & norm \\
\hline 37 & 32 & 18.6 & 3.5 & 5 & 4.6 & 4.3 & 0.9 & 0 & Adequate & & & $\begin{array}{l}\text { Toxic } \\
\text { Chan } \\
\text { neutr } \\
\text { Mark } \\
\text { reacti } \\
\text { lympl } \\
\text { few }\end{array}$ \\
\hline
\end{tabular}

\begin{tabular}{|c|c|c|c|c|c|c|c|c|c|c|c|c|}
\hline 38 & 23 & 9.1 & 2.4 & 1.8 & 2.4 & 2.1 & 0.3 & 0.2 & Adequate & Normal & 3.5 & $\begin{array}{l}\text { toxic } \\
\text { in } \\
\text { neutr } \\
\text { mod } \epsilon\end{array}$ \\
\hline 39 & 32 & 12.5 & 5.2 & 1.5 & 0.9 & 1.1 & 3.5 & 0.2 & Adequate & Normal & 3.3 & $\begin{array}{l}\text { Toxic } \\
\text { Chan } \\
\text { neutr } \\
\text { Mild }\end{array}$ \\
\hline 40 & 35 & 9.9 & 7.4 & 1.4 & 0.1 & 0.1 & 0.4 & 0.5 & Adequate & Normal & 3.9 & $\begin{array}{l}\text { toxic } \\
\text { in } \\
\text { neutr } \\
\text { mode }\end{array}$ \\
\hline 41 & 37 & 11.7 & 10.8 & 0 & 0.1 & 0.1 & 0.5 & 0.2 & Adequate & Normal & 3.7 & smuc \\
\hline 42 & 29 & 18.1 & 8.3 & 0.9 & 3.8 & 1.4 & 3.4 & 0.2 & Adequate & normal & 3 & $\begin{array}{l}\text { Toxic } \\
\text { in } \\
\text { neutr } \\
\text { mild }\end{array}$ \\
\hline 43 & 46 & $20-30 *$ & 0 & 0 & 0 & 0 & 0 & 0 & Adequate & normal & 4.5 & toxic \\
\hline
\end{tabular}

Page $13 / 22$ 


\begin{tabular}{|c|c|c|c|c|c|c|c|c|c|c|c|c|}
\hline 44 & 32 & 13.7 & 11.4 & 0.1 & 1.4 & 0.3 & 0.4 & 0.1 & Adequate & normal & 1.9 & NSF \\
\hline 45 & 35 & 12.8 & 8.4 & 0.5 & 1.5 & 0.3 & 1.5 & 0.5 & Adequate & normal & 3.9 & $\begin{array}{l}\text { Toxic } \\
\text { in } \\
\text { neutr } \\
\text { mild }\end{array}$ \\
\hline 47 & 40 & 18.1 & 15.9 & 0.2 & 0.2 & 0.4 & 1.3 & 0.2 & Adequate & normal & 3.6 & NSF \\
\hline 48 & 38 & 35 & 25.9 & 1.4 & 0.4 & 1.8 & 3.2 & 2.4 & Adequate & normal & 5 & NSF \\
\hline 49 & 45 & 14.9 & 11.9 & 1.6 & 0.4 & 0.1 & 0.6 & 0.1 & Adequate & normal & 5.7 & $\begin{array}{l}\text { Toxic } \\
\text { in } \\
\text { neutr } \\
\text { mild }\end{array}$ \\
\hline 51 & 40 & 15.7 & 12.2 & 1.1 & 0.3 & 0.8 & 1.3 & 0 & Adequate & normal & 4.5 & $\begin{array}{l}\text { Toxic } \\
\text { in } \\
\text { neutr } \\
\text { mild }\end{array}$ \\
\hline
\end{tabular}

Table 3b. Serum biochemistry values for the 48 free ranging red-tailed hawks included in final study. (-) Indicates not run due to insufficient sample size 


\begin{tabular}{|c|c|c|c|c|c|c|c|c|c|c|c|c|c|}
\hline $\begin{array}{l}\text { Hawk } \\
\text { study } \\
\#\end{array}$ & $\begin{array}{l}\text { Sodium } \\
(\mathrm{mEq} / \mathrm{L})\end{array}$ & $\begin{array}{l}\text { Potassium } \\
(\mathrm{mEq} / \mathrm{L})\end{array}$ & $\begin{array}{l}\text { Chloride } \\
(\mathrm{mEq} / \mathrm{L})\end{array}$ & $\begin{array}{l}\text { Uric } \\
\text { Acid } \\
(\mathrm{mg} / \mathrm{dL})\end{array}$ & $\begin{array}{l}\text { Calcium } \\
\text { (mg/dL) }\end{array}$ & $\begin{array}{l}\text { Phosphate } \\
(\mathrm{mg} / \mathrm{dL})\end{array}$ & $\begin{array}{l}\mathrm{TP} \\
(\mathrm{g} / \mathrm{dL})\end{array}$ & $\begin{array}{l}\text { Glucose } \\
(\mathrm{mg} / \mathrm{dL})\end{array}$ & $\begin{array}{l}\text { AST } \\
(\mathrm{U} / \mathrm{L})\end{array}$ & $\begin{array}{l}\text { GLDH } \\
(\mathrm{u} / \mathrm{L})\end{array}$ & $\begin{array}{l}\text { CK } \\
(U / L)\end{array}$ & $\begin{array}{l}\text { Bile } \\
\text { Acids, } \\
\text { Random } \\
\text { (umol/L) }\end{array}$ & Lipemia \\
\hline 1 & 158 & 2.5 & 117 & 9.2 & 9.9 & 3.9 & 3.7 & 358 & 2592 & 17 & 10499 & 17 & 2 \\
\hline 3 & 156 & 2.1 & 111 & 8.4 & 10.6 & 3.8 & 4.6 & 384 & 353 & 3 & 3207 & 2 & 5 \\
\hline 4 & 154 & 2.7 & 113 & 3.1 & 10.1 & 5 & 3.6 & 290 & 293 & 1 & 3311 & 0 & 18 \\
\hline 5 & 158 & 2.4 & 119 & 2.6 & 9.7 & 3.9 & 3.6 & 292 & 766 & 1 & 4343 & 2 & 7 \\
\hline 6 & 154 & 4.5 & 119 & 18.9 & 7.7 & 4 & 1.3 & 364 & 623 & 3 & 11536 & 5.4 & 8 \\
\hline 7 & 152 & 2.9 & 113 & 5.1 & 9.1 & 3 & 3.2 & 424 & 1885 & 19 & 32572 & 3.1 & 5 \\
\hline 8 & 148 & 3.7 & 112 & 16.6 & 7.2 & 2.1 & 1.1 & 315 & 607 & 2 & 13994 & 6.9 & 48 \\
\hline 9 & 154 & 4 & 112 & 11.1 & 9.2 & 6.2 & 3.9 & 116 & 335 & 5 & 2722 & 15.4 & 0 \\
\hline 10 & 154 & 2.6 & 113 & 4.5 & 10.5 & 2.6 & 4 & 363 & 598 & 2 & 3592 & 2 & 5 \\
\hline 11 & 157 & 2 & 113 & 7.1 & 10.2 & 3.8 & 3.5 & 370 & 1880 & 7 & 19390 & 18 & 5 \\
\hline 12 & 153 & 3 & 118 & 2.8 & 8.5 & 2.6 & 2.8 & 490 & 1475 & 3 & $>10000$ & 4 & 0 \\
\hline 13 & 161 & 3.2 & 118 & 8.6 & 10 & 3.3 & 3.4 & 359 & 293 & 3 & 1296 & 4 & 45 \\
\hline 14 & 148 & 5.4 & 108 & 53.4 & 11.9 & 10.7 & 4.8 & 289 & 466 & 6 & 5287 & 16 & 3 \\
\hline 15 & 161 & 2.8 & 128 & 11.5 & 8.8 & 2.7 & 2.9 & 357 & 1181 & 75 & 15701 & 17 & 8 \\
\hline 16 & 157 & 3.2 & 121 & 7.1 & 9.6 & 3.9 & 3.4 & 336 & 223 & 1 & 890 & 2 & 6 \\
\hline 18 & 153 & 3.4 & 116 & 3.8 & 10.3 & 4.7 & 3.1 & 327 & 446 & 4 & 3722 & 5 & 4 \\
\hline 19 & 160 & 2.4 & 118 & 2.9 & 10.5 & 5.5 & 3.5 & 258 & 252 & 3 & 1087 & 6 & 6 \\
\hline 20 & 162 & 1.1 & 118 & 15.5 & 10.5 & 4.6 & 4.2 & 362 & 627 & 11 & 1980 & 16 & 51 \\
\hline 21 & 154 & 3.8 & 119 & 15 & 7.3 & 4.8 & 1.5 & 326 & 253 & 3 & 2942 & 3 & 2 \\
\hline 22 & 165 & $<1.5$ & 119 & 7.4 & 99 & 4.8 & 4 & 321 & 1050 & 9 & 4204 & 6 & 77 \\
\hline 23 & 159 & 3.9 & 123 & 9.7 & 10.1 & 5 & 3.4 & 293 & 964 & 2 & 9180 & 3 & 5 \\
\hline 24 & 155 & 3.7 & 120 & 8.9 & 11.6 & 5.4 & 4.1 & 319 & 256 & 3 & 960 & 25 & 13 \\
\hline 25 & 168 & 1.8 & 130 & 11.3 & 9.4 & 3.9 & 3.2 & 292 & 1510 & 62 & 14193 & 22 & 36 \\
\hline 26 & 154 & 4 & 119 & 17.7 & 9.5 & 4.9 & 2.3 & 273 & 452 & 4 & 2902 & 4 & 5 \\
\hline 27 & 154 & 1.7 & 114 & 5.2 & 9.9 & 2.9 & 4.1 & 351 & 388 & 3 & 3094 & 5 & 3 \\
\hline 28 & 158 & 2.9 & 123 & 8.1 & 9.5 & 3.1 & 2.9 & 425 & 3448 & 6 & 14662 & 10 & 3 \\
\hline 29 & 160 & 3.5 & 128 & 5.7 & 9.2 & 4.5 & 2.7 & 414 & 393 & 6 & 7982 & 8 & 1 \\
\hline 30 & 159 & 2.6 & 118 & 6.6 & 10.9 & 3.5 & 4.4 & 376 & 295 & 2 & 1882 & 4 & 11 \\
\hline 31 & - & - & - & 7.8 & 10 & 4 & 3 & 510 & 647 & 6 & 4845 & - & - \\
\hline 32 & 155 & 2.9 & 120 & 8.3 & 8.4 & 3 & - & 512 & 566 & 10 & $>2000$ & 3 & 19 \\
\hline 33 & 156 & 3.3 & 122 & 16.8 & 7.6 & 3.70 & 1.1 & 330 & 370 & 8 & 4586 & 9 & 3 \\
\hline 34 & - & - & - & 24.1 & 7.1 & 3.6 & 0.9 & 265 & 211 & & 2895 & - & - \\
\hline 35 & 154 & 4.3 & 113 & 19.7 & 9.8 & 4.1 & 2.7 & 346 & 379 & 7 & 2377 & 4 & 3 \\
\hline 36 & 152 & 3.3 & 117 & 2 & 8.8 & 4.3 & 2.5 & 339 & 395 & 4 & 1772 & 5 & 4 \\
\hline 37 & 144 & 2.7 & 106 & 6 & 9.7 & 7.5 & 5 & 331 & 306 & 6 & 1867 & 0 & 9 \\
\hline 38 & 149 & 2.7 & 115 & 8.9 & 8.9 & 3.6 & 2.7 & 388 & 674 & 3 & 5847 & 4 & 9 \\
\hline 39 & 158 & 3 & 124 & 12.2 & 8.7 & 4 & 2.6 & 353 & 8518 & 53 & 120622 & 7 & 2 \\
\hline 40 & 152 & 2.7 & 120 & 5 & 9.2 & 3.5 & 2.9 & 400 & 5515 & 6 & 90806 & 9 & 13 \\
\hline 41 & 158 & 2.1 & 119 & 7.9 & 8.4 & 2.9 & 2.6 & 356 & 2092 & 46 & $>10000$ & 9 & 45 \\
\hline 42 & 162 & 2.9 & 120 & 24.8 & 8.7 & 3.9 & 2.6 & 224 & 397 & 6 & 2871 & 21 & 5 \\
\hline 43 & 151 & 5.7 & 119 & 49.3 & 8.3 & 4.7 & 3.1 & 246 & 1550 & 4 & $>2000$ & 6 & 3 \\
\hline
\end{tabular}




\begin{tabular}{|c|c|c|c|c|c|c|c|c|c|c|c|c|c|}
\hline 44 & 155 & 3.8 & 120 & 22.8 & 7.6 & 4.9 & 1.7 & 269 & 273 & 5 & 2525 & 4 & 1 \\
\hline 45 & 154 & 2.5 & 113 & 17.5 & 8.8 & 4 & 2.9 & 348 & 285 & 7 & 1665 & 24 & 29 \\
\hline 47 & 150 & 3.8 & 119 & - & 9 & 2.9 & 3.1 & 409 & $>1000$ & $>2000$ & $>10000$ & - & - \\
\hline 48 & 176 & 2.9 & 130 & 59.2 & 10.7 & 8.1 & 3.8 & 445 & 1997 & 5 & 9660 & 34 & 57 \\
\hline 49 & 156 & 3.5 & 118 & 15.1 & 10.5 & 5.6 & 4.3 & 328 & 426 & 1 & 2232 & 8 & 6 \\
\hline 51 & 154 & 3.4 & 120 & 4.2 & 9.3 & 3.3 & 3.5 & 415 & 1952 & 9 & 8995 & 4 & 2 \\
\hline
\end{tabular}

Table 4. Blood and liver anticoagulants, along coagulation parameters for free ranging red-tailed hawks. (-) Indicates no sample available for submission. (*) indicates clotted sample that was not included in PT, RVVT and fibrinogen analysis. Samples with detectable anticoagulant are indicated in bold. 
Whole Blood (ppm)

\begin{tabular}{|c|c|c|c|c|c|c|c|c|c|c|}
\hline $\begin{array}{l}\text { Hawk } \\
\text { study } \\
\#\end{array}$ & Brodifacoum & Bromadiolone & Chlorphacinone & Difenacoum & Difethialone & Diphacinone & Warfarin & Brodifacoum & Bromadiolone & C \\
\hline 1 & 0.003 & $<0.02$ & $<0.2$ & $<0.02$ & $<0.07$ & $<0.2$ & $<0.02$ & \multicolumn{3}{|c|}{ Liver not collected } \\
\hline 2 & $<0.002$ & $<0.02$ & $<0.2$ & $<0.02$ & $<0.07$ & $<0.2$ & $<0.02$ & $<0.002$ & $<0.02$ & $<$ \\
\hline $3^{*}$ & $<0.002$ & $<0.02$ & $<0.2$ & $<0.02$ & $<0.07$ & $<0.2$ & $<0.02$ & \multicolumn{3}{|c|}{ Liver not collected } \\
\hline 4 & 0.006 & $<0.02$ & $<0.2$ & $<0.02$ & $<0.07$ & $<0.2$ & $<0.02$ & 0.234 & $<0.02$ & $<$ \\
\hline 5 & $<0.002$ & $<0.02$ & $<0.2$ & $<0.02$ & $<0.07$ & $<0.2$ & $<0.02$ & 0.08 & $<0.02$ & $<$ \\
\hline $6^{*}$ & \multicolumn{7}{|c|}{ No sample submitted } & \multicolumn{3}{|c|}{ Liver not collected } \\
\hline \multirow[t]{2}{*}{$7 *$} & $<0.002$ & $<0.02$ & $<0.2$ & $<0.02$ & $<0.07$ & $<0.2$ & $<0.02$ & \multirow{2}{*}{\multicolumn{3}{|c|}{ Liver not collected }} \\
\hline & & & & & & & & & & \\
\hline $8^{*}$ & $<0.002$ & $<0.02$ & $<0.2$ & $<0.02$ & $<0.07$ & $<0.2$ & $<0.02$ & \multicolumn{3}{|c|}{ Liver not collected } \\
\hline 9 & $<0.002$ & $<0.02$ & $<0.2$ & $<0.02$ & $<0.07$ & $<0.2$ & $<0.02$ & \multicolumn{3}{|c|}{ Liver not collected } \\
\hline 10 & $<0.002$ & $<0.02$ & $<0.2$ & $<0.02$ & $<0.07$ & $<0.2$ & $<0.02$ & \multicolumn{3}{|c|}{ Liver not collected } \\
\hline 11 & $<0.002$ & $<0.02$ & $<0.2$ & $<0.02$ & $<0.07$ & $<0.2$ & $<0.02$ & \multicolumn{3}{|c|}{ Liver not collected } \\
\hline $12^{*}$ & $<0.002$ & $<0.02$ & $<0.2$ & $<0.02$ & $<0.07$ & $<0.2$ & $<0.02$ & \multicolumn{3}{|c|}{ Liver not collected } \\
\hline 13 & $<0.002$ & $<0.02$ & $<0.2$ & $<0.02$ & $<0.07$ & $<0.2$ & $<0.02$ & 0.011 & $<0.02$ & $<$ \\
\hline 14 & \multicolumn{6}{|c|}{ No sample submitted } & & 0.005 & $<0.02$ & $<$ \\
\hline 15 & \multicolumn{6}{|c|}{ No sample submitted } & & \multicolumn{3}{|c|}{ Liver not collected } \\
\hline $17 *$ & $<0.002$ & $<0.02$ & $<0.2$ & $<0.02$ & $<0.07$ & $<0.2$ & $<0.02$ & 0.003 & $<0.02$ & $<$ \\
\hline 18 & $<0.002$ & $<0.02$ & $<0.2$ & $<0.02$ & $<0.07$ & $<0.2$ & $<0.02$ & $<0.002$ & $<0.02$ & $<$ \\
\hline 19 & $<0.002$ & $<0.02$ & $<0.2$ & $<0.02$ & $<0.07$ & $<0.2$ & $<0.02$ & \multicolumn{2}{|c|}{ Liver not collected } & \\
\hline 20 & $<0.002$ & $<0.02$ & $<0.2$ & $<0.02$ & $<0.07$ & $<0.2$ & $<0.02$ & \multicolumn{2}{|c|}{ Liver not collected } & \\
\hline 21 & \multicolumn{6}{|c|}{ No sample submitted } & & \multicolumn{3}{|c|}{ No liver collected } \\
\hline $22^{\star}$ & $<0.002$ & $<0.02$ & $<0.2$ & $<0.02$ & $<0.07$ & $<0.2$ & $<0.02$ & No liver collec & & \\
\hline
\end{tabular}

\begin{tabular}{|c|c|c|c|c|c|c|c|c|c|c|}
\hline 23 & $<0.002$ & $<0.02$ & $<0.2$ & $<0.02$ & $<0.07$ & $<0.2$ & $<0.02$ & \multicolumn{3}{|c|}{ No liver collected } \\
\hline 24 & $<0.002$ & $<0.02$ & $<0.2$ & $<0.02$ & $<0.07$ & $<0.2$ & $<0.02$ & \multicolumn{3}{|c|}{ No liver collected } \\
\hline 25 & \multicolumn{6}{|c|}{ No sample submitted } & & \multicolumn{3}{|c|}{ No liver collected } \\
\hline 26 & $<0.002$ & $<0.02$ & $<0.02$ & $<0.02$ & $<0.07$ & $<0.2$ & $<0.02$ & \multicolumn{3}{|c|}{ No liver collected } \\
\hline 27 & $<0.002$ & $<0.02$ & $<0.2$ & $<0.02$ & $<0.07$ & $<0.2$ & $<0.02$ & \multicolumn{3}{|c|}{ No liver collected } \\
\hline $28^{*}$ & $<0.002$ & $<0.02$ & $<0.2$ & $<0.02$ & $<0.07$ & $<0.2$ & $<0.02$ & \multicolumn{3}{|c|}{ No liver collected } \\
\hline 29 & $<0.002$ & $<0.02$ & $<0.2$ & $<0.02$ & $<0.07$ & $<0.2$ & $<0.02$ & 0.172 & $<0.02$ & $<$ \\
\hline 30 & $<0.002$ & $<0.02$ & $<0.2$ & $<0.02$ & $<0.07$ & $<0.2$ & $<0.02$ & 0.032 & $<0.02$ & $<$ \\
\hline 31 & $<0.002$ & $<0.02$ & $<0.2$ & $<0.02$ & $<0.07$ & $<0.2$ & $<0.02$ & 0.015 & $<0.02$ & $<$ \\
\hline 32 & $<0.002$ & $<0.02$ & $<0.2$ & $<0.02$ & $<0.07$ & $<0.2$ & $<0.02$ & \multicolumn{3}{|c|}{ No liver collected } \\
\hline 33 & $<0.002$ & $<0.02$ & $<0.2$ & $<0.02$ & $<0.07$ & $<0.2$ & $<0.02$ & \multicolumn{3}{|c|}{ No liver collected } \\
\hline 34 & $<0.002$ & $<0.02$ & $<0.2$ & $<0.02$ & $<0.07$ & $<0.2$ & $<0.02$ & $<0.002$ & $<0.02$ & $<$ \\
\hline 35 & $<0.002$ & $<0.02$ & $<0.2$ & $<0.02$ & $<0.07$ & $<0.2$ & $<0.02$ & 0.01 & $<0.02$ & $<$ \\
\hline 36 & $<0.002$ & $<0.02$ & $<0.2$ & $<0.02$ & $<0.07$ & $<0.2$ & $<0.02$ & $<0.002$ & $<0.02$ & $<$ \\
\hline 37 & $<0.002$ & $<0.02$ & $<0.2$ & $<0.02$ & $<0.07$ & $<0.2$ & $<0.02$ & $<0.002$ & $<0.02$ & $<$ \\
\hline 38 & $<0.002$ & $<0.02$ & $<0.2$ & $<0.02$ & $<0.07$ & $<0.2$ & $<0.02$ & $<0.002$ & $<0.02$ & $<$ \\
\hline 39 & $<0.002$ & $<0.02$ & $<0.2$ & $<0.02$ & $<0.07$ & $<0.2$ & $<0.02$ & 0.05 & $<0.02$ & $<$ \\
\hline
\end{tabular}

Page 17/22 


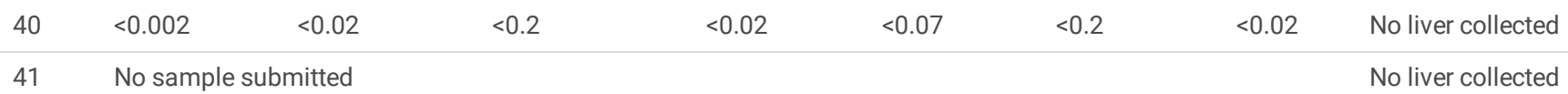

Table 5. Prothrombin (PT), Russell's viper venom (RVVT) times and fibrinogen for control red-tailed hawks

\begin{tabular}{llll} 
Hawk Study \# & PT (seconds) & RVVT (seconds) & Fibrinogen $(\mathrm{mg} / \mathrm{dL})$ \\
\hline C1 & 35.3 & 45.6 & 155 \\
\hline C2 & 32.4 & 27.1 & 193 \\
\hline C3 & 39.1 & 25.9 & 190 \\
\hline C4 & 39.7 & 70.5 & 153 \\
\hline C5 & 35.8 & 37.3 & 208 \\
\hline C6 & 33.9 & 30.3 & 205 \\
\hline C7 & 28.6 & 25.5 & 234 \\
\hline C8 & 34.9 & 39.3 & 174 \\
\hline C9 & 36.1 & 22.6 & 212 \\
\hline C11 & 37.5 & 29 & 183 \\
\hline C12 & 32.6 & 77.1 & 182 \\
\hline C13 & 31 & 91.8 & 112 \\
\hline C14 & 25.3 & 37 & 182 \\
\hline C15 & 22.6 & 21.2 & 166 \\
\hline C16 & 19.8 & 15.9 & 127 \\
\hline C17 & 23.7 & 47.7 & 168 \\
\hline C18 & 18.8 & 11.5 & 265 \\
\hline C19 & 18 & 16.7 & 326 \\
\hline C20 & 16.7 & 16.1 & 204 \\
\hline C21 & 22.1 & 44.1 & 15.9 \\
\hline C22 & 25.8 & & \\
\hline C23 & 21.4 & 309 \\
\hline
\end{tabular}

Table 6. Median, IQR, and range for coagulation time (sec) and fibrinogen ( $\mathrm{mg} / \mathrm{dL})$ in control birds, wild AR exposed birds, free-ranging AR not exposed birds, and free-ranging unknown exposure birds.

\begin{tabular}{|c|c|c|c|}
\hline & $\begin{array}{l}\text { PT } \\
\text { (seconds) }\end{array}$ & $\begin{array}{l}\text { RVVT } \\
\text { (seconds) }\end{array}$ & $\begin{array}{l}\text { Fibrinogen } \\
(\mathrm{mg} / \mathrm{dL})\end{array}$ \\
\hline Study Group & Median (IQR; range) & Median (IQR; range) & Median (IQR; range) \\
\hline $\begin{array}{l}\text { Control } \\
(n=22)\end{array}$ & $\begin{array}{l}29.8 \\
(21.9-35.4 ; 16.7-39.7)\end{array}$ & $\begin{array}{l}28.1 \\
(16.6-44.5 ; 11.5-91.8)\end{array}$ & $\begin{array}{l}186.5 \\
(165.3-217.5 ; 112.0-416.0)\end{array}$ \\
\hline $\begin{array}{l}\text { Free-range RTHs } \\
\text { AR detected in liver } \\
(n=9)^{A}\end{array}$ & $\begin{array}{l}31.9 \\
(19.9-34.9 ; 18.3-38.1)\end{array}$ & $\begin{array}{l}19.6 \\
(17.0-37.8 ; 13.7-40.1)\end{array}$ & $\begin{array}{l}315.0 \\
(226.5-419.5 ; 154.0-583.0)\end{array}$ \\
\hline $\begin{array}{l}\text { Free-range RTHs } \\
\text { AR not detected } \\
(n=5)\end{array}$ & $\begin{array}{l}26.8 \\
(22.7-40.2 ; 21.6-51.5)\end{array}$ & $\begin{array}{l}39.2 \\
(24.8-90.4 ; 18.0-90.7)\end{array}$ & $\begin{array}{l}162.0 \\
(104.5-271.0 ; 73.0-317.0)\end{array}$ \\
\hline $\begin{array}{l}\text { Free-range RTHs, } \\
\text { no AR analysis on liver } \\
(n=16)\end{array}$ & $\begin{array}{l}20.8 \\
(19.0-31.6 ; 18.3-43.9)\end{array}$ & $\begin{array}{l}19.1 \\
(13.8-35.7 ; 12.3-59.3)\end{array}$ & $\begin{array}{l}285.5 \\
(239.0-334.8 ; 58.0-472.0)\end{array}$ \\
\hline
\end{tabular}

A. descriptive statistics exclude one free-ranging RTH with PT and RVVT that exceeded the instruments' maximum clot detection times of 180 seconds. 
Table 7. Diagnosis based on necropsy results for red-tailed hawks necropsies in this study

\begin{tabular}{|c|c|c|}
\hline $\begin{array}{l}\text { Hawk } \\
\text { number }\end{array}$ & $\begin{array}{l}\text { Cause of } \\
\text { death }\end{array}$ & Diagnosis \\
\hline 8 & euthanasia & Emaciation, Aspergillus pneumonia and air sacculitis \\
\hline 14 & died & $\begin{array}{l}\text { Pulmonary, hepatic and coelomic aspergillosis, bacterial stomatitis, bacterial blepharitis and keratitis (bilateral) with unilateral } \\
\text { anterior uveitis }\end{array}$ \\
\hline 42 & died & $\begin{array}{l}\text { hemoparasitism (likely leucocytozoon infection), severe, with splenic megaloschizont- probably associated with anemia. } \\
\text { Intestinal coccidiosis, marked, likely due to Sarcocystis sp. emaciation and starvation }\end{array}$ \\
\hline 43 & died & $\begin{array}{l}\text { West Nile virus infection with myocardial necrosis (acute and severe) and vascular necrosis- confirmed by IHC of brain } \\
\text { (extensive), heart, kidney and serosas. Hemoparasitism, probably due to Haemoproteus sp, marked. Intestinal coccidiosis, } \\
\text { marked, probably due to Sarcocystis sp. }\end{array}$ \\
\hline 47 & euthanasia & $\begin{array}{l}\text { cerebral necrosis, focally extensive, with hemorrhage- possible larva migrans or trauma. Lung microgranuloma with nematode } \\
\text { larvae- probable larva migrans. Pneumonia, interstitial, fibrinous, focally extensive (mediastinum) with associated mediastinal } \\
\text { pleuritis and air sacculitis. Hepatitis, multifocal, mild to moderate, chronic-active (possibly also associated with larva migrans) }\end{array}$ \\
\hline
\end{tabular}

\section{Figures}
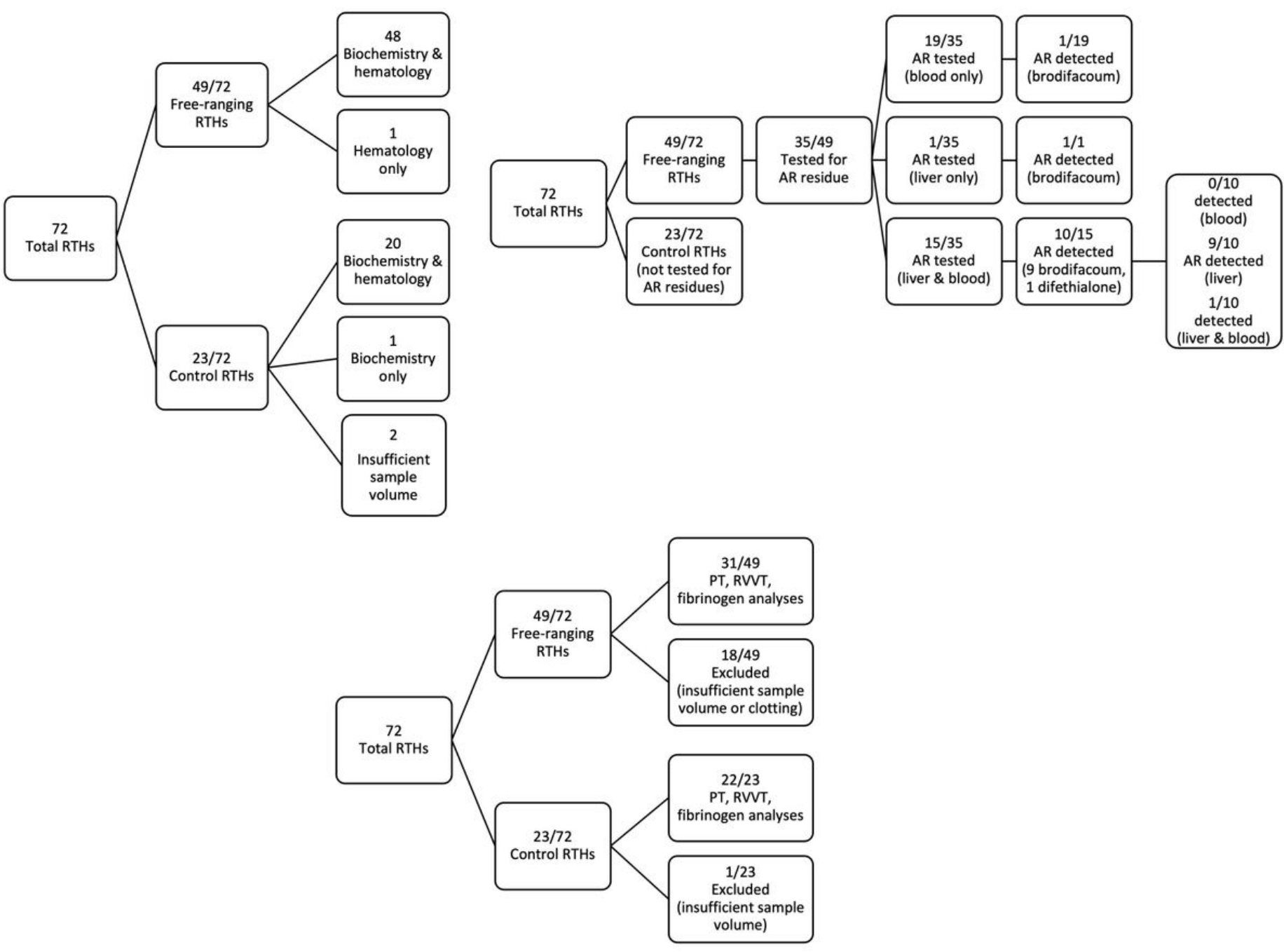

\section{Figure 1}

a. Description of anticoagulant rodenticide (AR) residue analyses for control and free ranging red-tailed hawks (RTHs).

b. Description of coagulation parameter analyses for control and free ranging red tailed hawks (RTHs) including prothrombin time (PT), Russell's viper venom time (RVVT), and fibrinogen.

c. Description of hematology and biochemistry results available for control and free ranging red-tailed hawks (RTHs). 

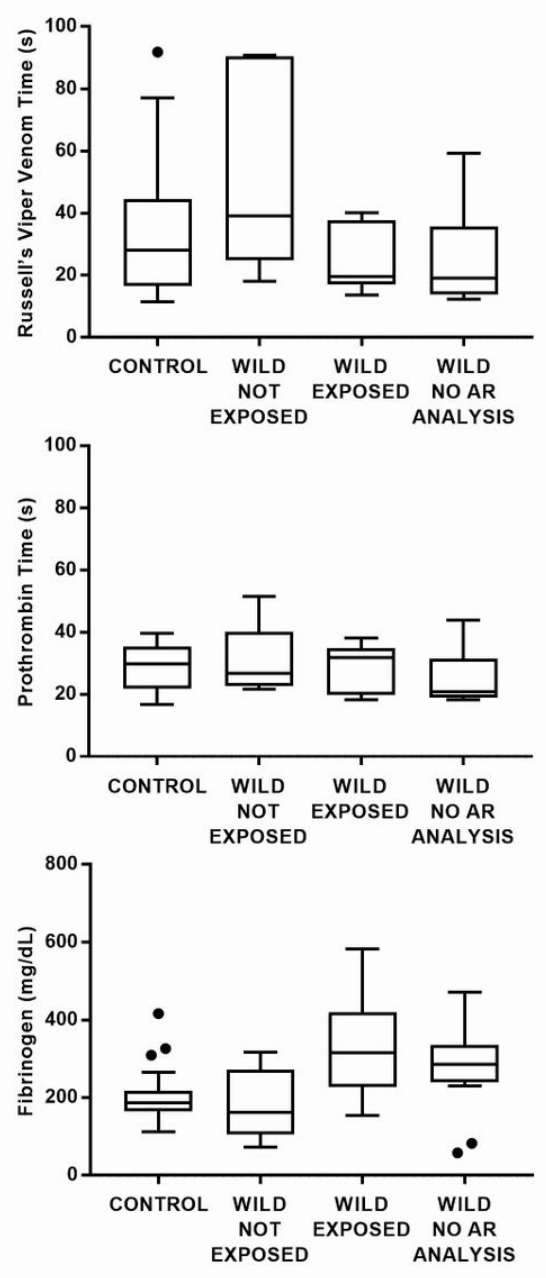

\section{Figure 2}

RVVT, PT and fibrinogen in control, free-ranging AR exposed, free-ranging AR not exposed, and free-ranging unknown exposure RTHs using the Tukey method for plotting whiskers and outliers (Tukey, 1977). 


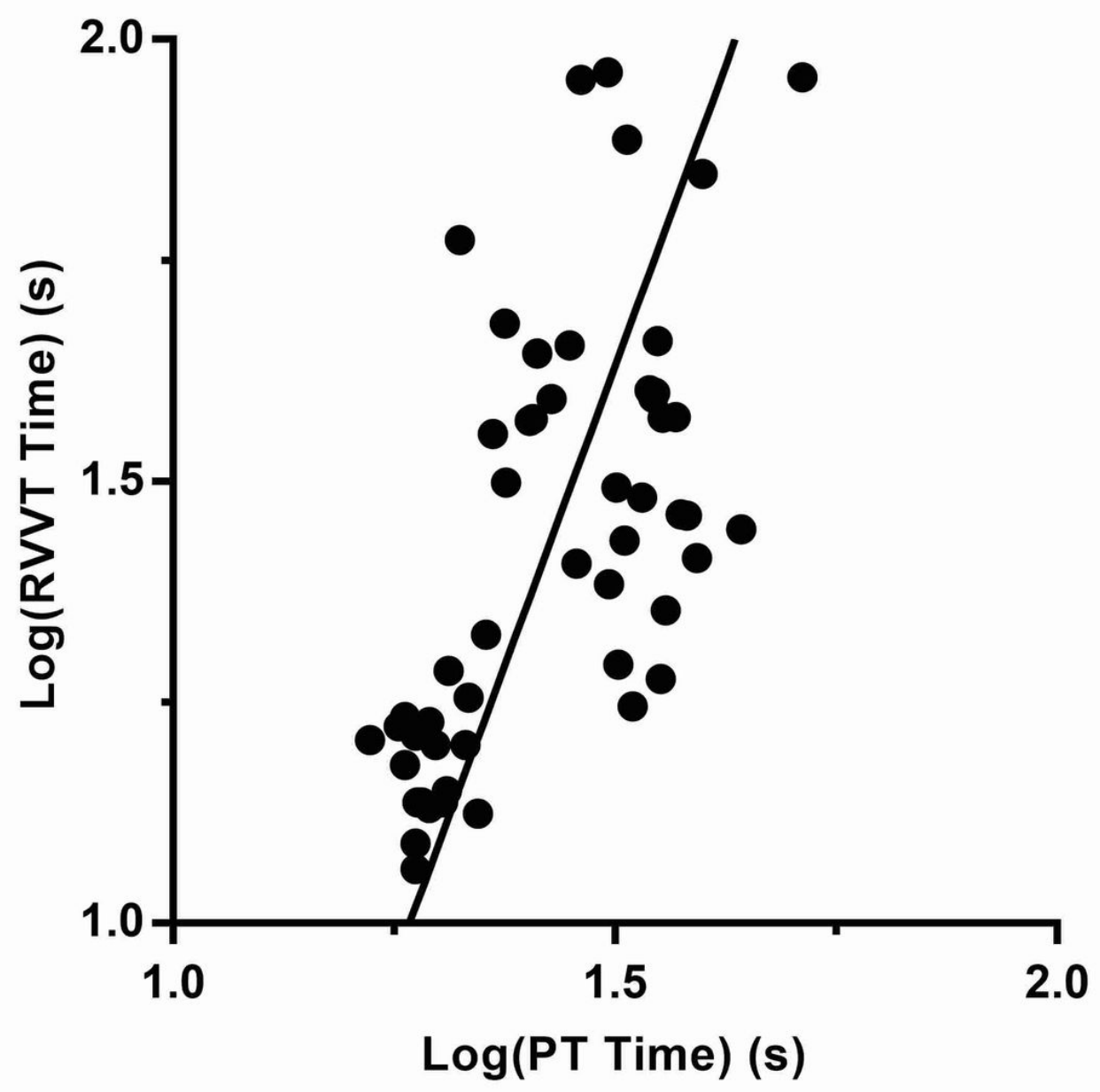

Figure 3

Deming regression analysis of log-transformed coagulation times obtained by RVVT and PT assays. 


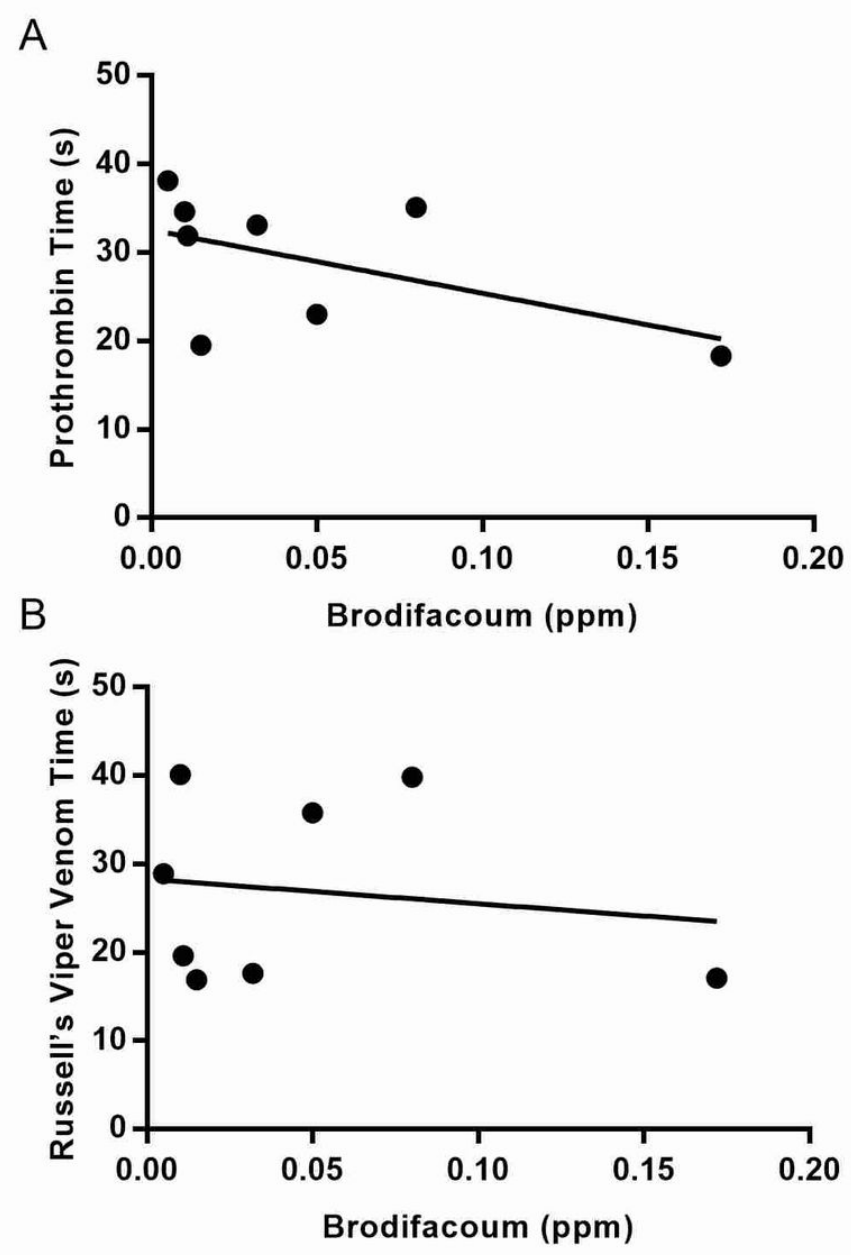

Figure 4

Regression of coagulation time (seconds) on liver brodifacoum concentration (ppm) for PT and RVVT methods. 